\title{
Manufacturer, Supermarket, and Grocer Liability for Contaminated Food and Beverages due to Negligence, Warranty, and Liability Laws
}

\author{
Frank J. Cavico ${ }^{1}$ \\ Bahaudin G. Mujtaba ${ }^{2 \rtimes}$ \\ Stephen Muffler ${ }^{3}$ \\ Marissa Samuel $^{4}$ \\ Nicolas-Michel Polito ${ }^{5}$
}

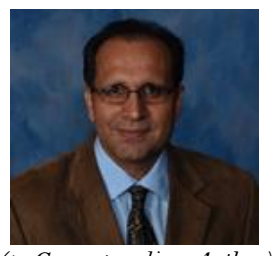

'The H. Wayne Huizenga College of Business and Entrepreneurship Nova Southeastern University, USA

Nova Southeastern University, USA

Email:mujtaba@nova.edu

${ }^{3}$ University of Miami, USA

${ }^{4}$ Columbia University, USA

${ }_{5}^{5}$ Fairleigh Dickenson University, USA

\begin{abstract}
Foodborne illnesses linked to Salmonella, Norovirus, Listeria, and Escherichia coli (E. Coli) are a serious problem people all over the world as they tend to negatively impact about ten to fifteen percent of every population. In this article, we focus on who is legally responsible for the proper handling of foods and the legal redress harmed consumers have in recovering damages. This article examines three legal doctrines that the injured consumer can use to sue parties on the food chain - the common law tort of negligence, warranty law based on statutory law - the Uniform Commercial Code, and the common law tort of strict liability. The article provides a legal overview of the three legal doctrines wherein basic principles and elements are set forth and illustrated, while examining them in the context of recent food and beverage case law involving manufacturers, supermarkets, and grocers. Based on the legal analysis, the knowledge and experience of the authors, as well as insights gained from legal and management commentary, the authors discuss the implications of food and beverage liability for employers and managers in the food chain. Finally, we provide recommendations to employers and managers on how to properly handle safety standards in order to avoid liability for foodborne illnesses and accidents.
\end{abstract}

Keywords: Food manufacturer, Food contamination, Food adulteration, Negligence, Warranty, Wholesomeness, Strict liability, Defect.

Citation | Frank J. Cavico; Bahaudin G. Mujtaba; Stephen Muffler; Marissa Samuel; Nicolas-Michel Polito (2018). Manufacturer, Supermarket, and Grocer Liability for Contaminated Food and Beverages due to Negligence, Warranty, and Liability Laws. Economy, 5(1): 17-39. History:

Received: 23 May 2018

Revised: 10 July 2018

Accepted: 4 September 2018

Published: 21 September 2018

Licensed: This work is licensed under a Creative Commons

Attribution 3.0 License $(\mathbf{c c}) \mathbf{E Y}$

Publisher: Asian Online Journal Publishing Group
Contribution/Acknowledgement: All authors contributed to the conception and design of the study.

Funding: This study received no specific financial support

Competing Interests: The authors declare that they have no conflict of interests.

Transparency: The authors confirm that the manuscript is an honest, accurate, and transparent account of the study was reported; that no vital features of the study have been omitted; and that any discrepancies from the study as planned have been explained.

Ethical: This study follows all ethical practices during writing.

\section{Contents}

1. Introduction

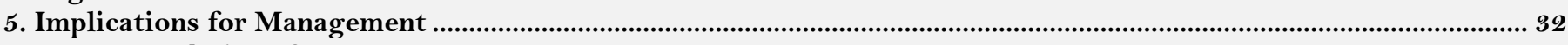

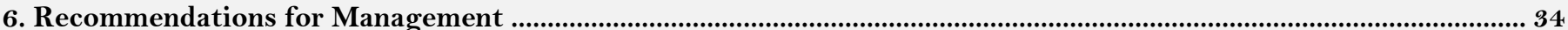

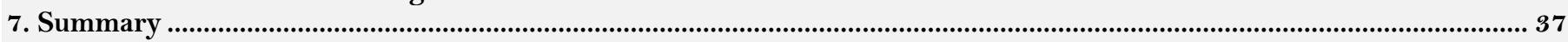

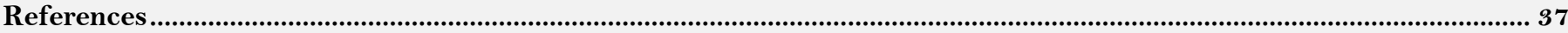




\section{Introduction}

Foodborne illnesses are a serious problem in the United States. Cogan (2016) using data from the Centers of Disease Control and Prevention, reports that one in six people in the U.S., approximately 48 million, suffer from foodborne illnesses annually, which are principally caused by Salmonella, Norovirus, Listeria, and Escherichia coli (E. Coli). Moreover, annually, 128,000 people require hospitalization and 3000 die from foodborne illnesses (Cogan, 2016). What legal redress do these harmed consumers have? That question is the essence of this article.

The issue of the legal liability for contaminated food is even more pronounced today because many supermarkets and grocers are now engaging in much more take-out food business; and, moreover, the food meals and items involved are a lot more sophisticated and complex than past more basic offerings. The Wall Street Journal (Haddon and Nassauer, 2016; Newman, 2016) pointed out three recent contamination examples: Whole Foods Market, Inc. was ordered by the Food and Drug Administration (FDA) to commercially close one of its commercial kitchens that produced fresh meals for stores due to concerns about safety lapses in a Boston-area facility which resulted in a listeria outbreak; also in 2016, an E. Coli outbreak that sickened 19 people that was linked to rotisserie chicken salad that was made at Costco Wholesale Corp.; and deli foods from the Boise Co-Op, a natural foods grocer in Idaho, were tied to a salmonella outbreak in 2015 that made almost 300 people sick. The Wall Street Journal (Haddon and Nassauer, 2016; Newman, 2016) further reported that the U.S. Centers for Disease Control and Prevention indicated that food contamination outbreaks doubled from 2014 to 2015, where in that latter year 23 outbreaks occurred, 572 people were sickened, and 42 people were hospitalized. Salmonella was the most frequent outbreak linked to stores, followed by the norovirus (Haddon and Nassauer, 2016; Newman, 2016). Nevertheless, freshly prepared meals are plainly now "big business." The Wall Street Journal (Haddon and Nassauer, 2016; Newman, 2016) reported that in 2005 freshly-prepared foods generated $\$ 15$ billion in sales, but that amount nearly doubled to approximately $\$ 28$ billion in 2015. Fortune (Kell, 2016) recently profiled one of these new companies called Blue Apron, which bills itself as a "meal-kit-delivery startup" company, selling meal kits (recipes and ingredients) using an "eclectic mix" of "precise" oils, spices, proteins and farm-fresh foods as well as other ingredients (Kell, 2016). One meal example is a summer green salad with green beans and carrots, grilled barramundi on top of an heirloom-tomato salad with smashed crispy fingerling potatoes. The company is just four years old and is valued at $\$ 2$ billion with 4000 employees, selling 8 million meal kits a month, which cost $\$ 9.99$ per person or $\$ 8.74$ each for a family plan, excluding delivery costs (Kell, 2016). Furthermore, as reported in the Wall Street Journal (Haddon and Nassauer, 2016). Amazon.com, has developed an e-commerce fresh food business, called Amazon Fresh, which is aggressively competing with traditional grocers and other online food merchants. In 2014, the Wall Street Journal (Haddon and Nassauer, 2016) reported that Amazon and other online food merchants achieved $\$ 6.3$ billion in sales, which amount was up 20\% from 2013.

When it comes to information related to the safety of food items and ingredients, regardless of how or where purchased, the consumer is in a decidedly disadvantageous position. Cogan (2016) explains:

Consumers are burdened by significant informational asymmetries with respect to the food they eat. Possessing less information than farmers, processors, transporters, retailers and others who grow, handle, prepare, and sell food, consumers cannot fully discern risky food from safe food. Was the food dropped on the floor? Was it exposed to contaminants and pathogens? Consumers almost never know. Furthermore, the nature of foodborne illness creates its own information problems. The period of time between infection by a pathogen and the onset of symptoms is variable. Some foodborne illnesses take a few hours to develop, while others can take a week or more. This not only makes it harder for victims of foodborne illness to link their sickness to a particular food, but the passage of time increases the likelihood that evidence of the contaminated food (i.e., the leftovers) will be unavailable for testing - thereby severing the empirical connection between the illness and its food source (pp. 1501-1502).

Yet despite the aforementioned informational and practical problems, the consumer harmed by unsafe food or beverage products does have certain legal avenues to pursue to achieve redress. As such, in this article we examine the common law tort of negligence, warranty law based on statutory law - the Uniform Commercial Code, and the common law tort of strict liability.

\section{Definitions}

Food contamination or contaminated food is the presence in food of harmful, unpalatable, or otherwise foreign substances, for example, microorganisms, diluents, dirt, dust, chemicals, toxic substances, microbes, and/or organisms, before, during, or after processing or storage, which can cause consumer illness (Encyclopedia of Medical Concepts, 2016; Wikipedia, 2016). Adulterated food, generally speaking, is food that is not pure, safe, or wholesome because it contains poisonous or deleterious substances or contains foreign matter, filth or food that is otherwise contaminated, and thus the food is injurious to health (Wikipedia, 2016). Note that the federal government in the Food, Drug, and Cosmetic Act and the Federal Meat Inspection and the Poultry Products Inspection Act has other detailed and technical standards of what makes food "adulterated," including impermissible and permissible pathogens (that is, microorganisms such as bacteria) in certain types of food (U.S. Legal - Legal Definitions, 2016; Wikipedia, 2016) but such a scientific micro-biological examination is beyond the scope of this article. Finally, foodborne illness, also known as foodborne disease or food poisoning, is any illness resulting from contaminated food (Wikipedia, 2016). It should be noted that States also have food adulteration statutes (Cousineau, 2010).

\section{Limitations}

This article has certain limitations. First, the article examines the liability of food manufacturers, supermarkets, and grocers. The authors cover the liability of restaurants in a separate academic effort, though some references to restaurants are made in this work. Second, the article primarily deals with the three conventional legal doctrines as designated in the title and briefly addressed in the Introduction, all of which are based on state law. Negligence and strict liability are, as noted, torts, based on the common law of the states; and warranty law is based on the 
Uniform Commercial Code, which is a form of state statutory law. Accordingly, the areas of the law examined herein are highly dependent on the law of several states, which of course can vary; and, moreover, there actually may be contradictions in interpretation on the appellate level in the states, which ultimately the Supreme Court of the state will have to resolve. So, for a particular lawsuit reference must be made to the law of the state having jurisdiction or if a federal "diversity" case (that is, the parties are from different states and the case is heard in federal court) to the law of the state where the injury or harm occurred (Cavico and Mujtaba, 2014). There is also a vast array of detailed federal law dealing with food safety, most prominently regulatory law emanating from the federal Food and Drug Administration, especially since the agency was further empowered to regulate by the Food Safety Modernization Act of 2011 which aims to prevent food contamination. A failure to comply with government statutory or regulatory standards does impact negligence liability, as will be seen and explained. Secondly, the article only deals with food and beverages that are contaminated in the traditional sense of being unwholesome or having foreign objects therein. Accordingly, the article does not extensively examine the growing area of the law dealing with the legal liability when food or beverages lack "warnings" as to calorie counts, fats, cholesterol, and sugar, among other perceived harmful substances. Similarly, the authors do not extensively cover the area of law dealing with the alleged "defectiveness" of food or beverages because they were not designed better to be more healthful. The authors will mention these areas, but save the health "warnings" (or lack thereof) and "design defects" aspect of food and beverage law for other future academic efforts. Finally, this article does not deal with the liability of the cruise lines since that examination would be in the highly specialized areas of admiralty law and international treaties.

\section{Legal Overview}

One academic study of 320 litigation and arbitration cases filed against food distributors, manufacturers and retail outlets revealed some interesting statistics. The evaluation of this study found as follows:

The 320 defendants in the dataset were comprised of 44 distributers, 45 manufacturers, and 231 retail outlets or restaurants... The average resolution for cases involving distributers was $\$ 343,999$ with a minimum of $\$ 0$ and a maximum of $\$ 4.75$ million. Of the 44 cases against distributors, 29 cases (or $66 \%$ of the total) went to trial and reached a jury verdict, 12 (27\%) were settled, and $3(7 \%)$ went to arbitration. The average resolution for cases involving manufacturers was $\$ 284,394$ with a minimum of $\$ 0$ and a maximum of $\$ 3$ million. Of the 45 cases against manufacturers, 16 (or $36 \%$ of the total) went to trial and reached a jury verdict, $21(48 \%)$ were settled, and 7 cases $(16 \%)$ were resolved through arbitration. Interestingly, $88 \%$ of cases against manufacturers resulted in monetary damages awarded to the plaintiff, as opposed to $59 \%$ of cases against distributers and $61 \%$ of cases against restaurants (Marks, 2013).

However, these statistics show a low occurrence of litigation relative to food borne illnesses, which fact suggests that they are reflective of how difficult it is to prove under any theory of recovery (Cogan, 2016).

Nevertheless, an injured party can sue for any or all of the legal theories to be examined herein as well as any others supported by the facts and the law. The legal theories will be separate parts or "counts" of a lawsuit. As such, if one or more is dismissed by the court or ruled against by a jury the plaintiff may be able to sustain his or her case on another "count." For example, in Goodman v. Wenco Foods Inc (1992) the Supreme Court of North Carolina dismissed the negligence claim but allowed the merchantability claim based on the Uniform Commercial Code to go to the jury. Similarly, in the New Jersey Supreme Court case of Hollinger v. Shoppers Paradise of New Jersey Inc (1975) involving a consumer who contracted trichinosis from eating pork chops, the court ruled that though there was no evidence of negligence in the handling of the meat, the case nonetheless could proceed on the theories of the implied warranty of merchantability and strict liability in tort as the latter two theories do not require proof of negligence by the defendant.

\section{A. The Tort of Negligence}

\section{Generally}

Negligence is a form of conduct, but conduct that can give rise to liability under the common law based on the tort, or civil wrong, of negligence. The traditional elements or components of the tort of negligence are as follows: 1) the existence of a duty, imposed by law, requiring persons to conform to a certain standard of conduct, to wit, the "reasonable person" standard; 2) a failure on a person's part to conform to the aforementioned standard, that is, a breach of the duty; 3) causation, that is, a reasonably close nexus or connection between the conduct and the resulting harm, consisting in causation-in-fact as well as "legal" cause, which latter cause is also referred to as "proximate cause"; and 4) an actual loss, harm, or damage resulting from the conduct (Keeton et al., 1984; Clarkson et al., 2012; Cavico and Mujtaba, 2014; Cheeseman, 2016). The burden of proof and persuasion are on the plaintiff bringing the lawsuit to demonstrate that the elements of the tort are present (Gant v. Lucy Ho's Bamboo Garden, 1984).

Although the tort of negligence in the United States is based on state law, the fundamental elements of the tort, originally stemming from the old common law of England, as well as the elements of the tort as applied in the context herein, are generally consistent among the several states. A general review of various state jurisdictions reveals that the courts are fairly divided as to what may constitute initial evidence of negligence in food cases: Georgia, Iowa, Louisiana, New York, and New Jersey have found that illness or injury following ingestion establishes a prima facie case, while Alabama, Colorado, Illinois, Massachusetts, Mississippi, North Carolina, Tennessee, and Washington have not (Spahn, 2011). In the next section of the article these elements are explicated both generally and in the context of food and beverage liability.

\section{Elements}

\section{a. Duty}

The first requirement to a negligence cause of action is the duty element. The duty, imposed by the law, is one of due care. The duty to conform one's conduct to the conduct of a "reasonable person" is the essence of negligence law. As explained by Keeton et al. (1984): 
The whole theory of negligence presupposes some uniform standard of behavior.... The standard of conduct which the community demands must be an external and objective one, rather than the individual judgment, good or bad, of the particular actor; and it must be, so far as possible, the same for all persons since the law can have no favorites.... The courts have dealt with this very difficult problem by creating a fictitious person....Sometimes he is described as a reasonable person, or a person of ordinary prudence, or a person of reasonable prudence (pp. 173-74).

A jury typically is the lay body of citizens which determines if the duty to act as a reasonably prudent person was violated or breached. As further explained by Keeton et al. (1984): "The conduct of the reasonable person will vary with the situation with which he is confronted. The jury must therefore be instructed to take the circumstances into account; negligence is a failure to do what a reasonable person would do 'under the same or similar circumstances." This general duty of care attaches to both pre- and post-sales of products. Under California law, for example, there is a duty owed by supermarkets to warn potential customers of a food product recall as well as a duty to warn those customers that have already purchased the food product (Hensley-Maclean v. Safeway Inc, 2014).

\section{b. Breach of Duty}

Once a legal duty has been established by the court (that is, the judge, who decides issues of law) then, typically, unless waived, a jury (which decides issues of fact) must be empaneled to determine the factual issue of whether the defendant has breached or contravened the duty. A breach of duty occurs when a defendant fails to exercise due care and thus fails to act as a reasonable person (Keeton et al., 1984; Clarkson et al., 2012; Cavico and Mujtaba, 2014; Cheeseman, 2016). The burden of persuasion in demonstrating a breach to the jury is on the plaintiff bringing the lawsuit; and the standard of proof that the jury will use is the one characteristic for a civil case, such as negligence, the "preponderance of the evidence," standard (colloquially referred to as " $50 \%$ plus 1" of the evidence) (Keeton et al., 1984).

However, conversely, it needs to be pointed out that evidence of a lack of due care will defeat a negligence claim. To illustrate, CNN.com reported on a situation where a man found the remnants of a frog or toad in his can of Diet Pepsi after he had consumed some of the beverage and became sick. He called the Food and Drug Administration (FDA) as well as poison control. The FDA investigated the local Pepsi bottling plant, but “...did not find any adverse conditions or association to this problem," and thus the agency had "not determined when or how the contamination occurred," and was "simply unable to determine when or how the specimen entered the package" (Grinberg, 2009). Moreover, evidence of the presence of due care, for example, that a defendant producer or seller met or exceeded government standards, may defeat a negligence claim since there would be no breach of the duty of care. For example, in Goodman v. Wenco Foods Inc (1992) evidence that the defendant hamburger seller's ground beef processing standards exceeded U.S.D.A. requirements was sufficient for the court to dismiss a negligence claim.

One interesting case distinguishes the levels of duty of care between a mere grocer, who sells pre-packaged self-contained food products, and the manufacture of such items in a deleterious food negligence claim. In Simmons v. Brookshire Grocery Company d/b/a Brookshire's Food and Pharmacy (2016) a customer of the grocer purchased fruit cups and became ill after eating them. He sued under various theories, including negligence, seeking damages relative to the consumption of deleterious food. The court presumed the facts most favorable to the plaintiff as follows when considering the defendant's summary judgment motion:

Simmons alleged that on Friday, February 15, 2013, he went to the Brookshire's on North Market Street in Shreveport and bought four packages of Del Monte "Peaches in Peach" fruit cups. Each package consisted of four clear-plastic cups with clear-plastic peel-off lids, stacked top-to-top, and held together in a cardboard wrapper that covered most of the product but allowed a view of a portion of each plastic cup. He ate one of the cups around 10:00 p.m. that night, went to bed, and started feeling sick around 3:30 a.m. He got up and ate another cup, "to settle my stomach," but noticed it tasted slightly different from the first: he thought it was just a peach hull. Around 7:00 a.m. he opened the remaining cups and then, for the first time, noticed a small patch of mold around the rim of the cup. He took pictures of the cups, returned them to Brookshire's and got a refund. However, later that day he started having cramps and nausea, then vomiting, and then constipation. On Monday, February 18, he went to David Raines Community Health Center, and testified that he received medicine for food poisoning (Simmons v. Brookshire Grocery Company d/b/a Brookshire's Food and Pharmacy, 2016).

The court distinguished the duty to inspect pre-packaged food items differently between grocery store owner versus a food manufacturer. The court explained that this particular grocery store did not take part in the preparation, processing or manufacturing of the product, or subjected the product to improper care. In affirming the summary judgment in favor of the grocer, the appeals court explained its holding as follows:

We find that Simmons has failed to offer evidence to create a genuine issue under the applicable law. There is absolutely no evidence that Brookshire's took part in the preparation, processing or manufacturing of the Del Monte fruit cup consumed by Simmons. Further, there is nothing but speculation that Brookshire's mishandled, disturbed or subjected the fruit cup to improper care; Simmons himself testified that the cardboard wrapper and the plastic cups were intact, and no store employee was deposed to show any mishandling. In short, Brookshire's has shown lack of support for the essential elements of a claim under Le Blanc and Ard, supra, [seminal case precedent relied upon by the appeals court] and Simmons has not supplied the evidence that would create a genuine issue.

Finally, Simmons argues that if Brookshire's employees had "inspected their products more closely," they would have seen the mold on the product through the clear packaging. Although Le Blanc and Ard impose liability on a grocer only for mishandling, disturbing or subjecting the product to improper care, there is no liability for failure to conduct a "close" inspection. The fruit cups are packaged top-to-top, with the cardboard wrapper covering much of the sides. Simmons's photographs show a small area of mold near the rim, at the top of one plastic cup. Any inspection sufficient to discover this would be incredibly intense, 
requiring the removal of wrappers and close examination under the peel-off lids. The law does not require this degree of invasive, or destructive, inspection (Simmons v. Brookshire Grocery Company $\mathrm{d} / \mathrm{b} / \mathrm{a}$ Brookshire's Food and Pharmacy, 2016).

In certain states, a grocery store's duty of care owed to their patrons may also sometimes obligate grocery store managers to personal liability if they fail to fulfill this duty. In the case of Hutchen v. Wal-Mart Stores East I LP. \& Juden (2008) a customer of Wal-Mart alleged that spinach he purchased from the store was infected with E. Coli bacteria and sued the store and its manager for negligence. The plaintiff's complaint alleged the following against both defendants collectively:

1. Defendants failed to have in place proper and appropriate processing procedure for the detection of contaminated food, and in particular contaminated Spinach though they knew or should have known of the risk of such contamination;

2. Defendants continued to market contaminated Spinach though they knew or should have known of the contamination of the product in other states and stores;

3. Defendants continued to market contaminated Spinach though they knew or should have known of a recall of the product in other states and stores;

4. Defendants failed to remove contaminated Spinach from the shelves in a timely fashion or warn of possible contamination;

5. Defendants sold contaminated Spinach to the Plaintiff.

In examining the legitimacy of the claim against the store manager, the court explained that since the plaintiffs petition "alleged, inter alia, that store manager Juden was negligent because she "knew or should have known" that contaminated spinach had been found in other states and stores and had been recalled in other states and stores, but she failed to remove contaminated spinach from the Dexter Wal-Mart shelves and failed to warn customers of possible contamination, such knowledge creates a duty as a matter of Missouri law" (Hutchen v. Wal-Mart Stores East I LP. \& Juden, 2008).

However, a grocery store has no duty to customers if it never had control over the food product whatsoever before or at the time of sale. The court in the case of Campbell v. Supervalu Inc (2008) examined a customer's claim that they purchased ground beef that was tainted with E. Coli and which was served in Hamburger Helper to their child making him ill. Thirteen years later, the lawsuit was filed to recover damages for the child's complications of acute renal failure, onset of insulin dependent diabetes mellitus, congestive heart failure, and chronic renal failure alleged to have occurred because of the E. coli. The court granted the grocer's summary judgment not only on the basis of the Statute of Limitations running, but also because the defendant company did not own the grocery store at the time of the sale of the product and thus did not owe the plaintiff a duty of care. Specifically, the court explained:

Therefore, from a legal perspective, on September 22, 1993, Supervalu had no legal duty to the Campbells as a matter of law..... 'Whether a defendant owes a duty of care to a plaintiff is a question of law for the court to decide' Bowman v. Tippmann Enters. (868 N.E.2d 1172, 1174) relationship between the parties, the reasonable foreseeability of harm, and public policy concerns' (Campbell v. Supervalu Inc, 2008).

Once a jury determines that the defendant acted in an unreasonable manner, and consequently the duty of care has been breached, the next issue for the jury to determine is the causation element to a negligence lawsuit.

\section{c. Causation - Factual and Proximate}

Causation is an essential element to a lawsuit for negligence; and there are two types of causation. One is called "factual causation" (or at times "actual" or "cause-in-fact") and the other is called "legal causation" or (perhaps better because less confusing) "proximate causation." Factual causation is simply a question of scientific fact, that is, as a matter of science, and regardless of how long, attenuated, or convoluted the causation chain, did careless act "A" cause ultimate harm "Z"? If the answer is "yes," then factual causation is present (Keeton et al., 1984; Clarkson et al., 2012; Cavico and Mujtaba, 2014; Cheeseman, 2016). Causation can be established by direct evidence, circumstantial evidence, expert testimony, lay testimony, or some combination thereof (Southern States Coop v. Doggett, 1982; McCarley v. West Quality Food Service, 1998). The standard of proof for factual causation is the usual civil "preponderance of the evidence" standard; that is, the evidence presented by the injured plaintiff must show that it was more likely than not that the allegedly harmful food caused the plaintiff's injury (Jackson v. Winn Dixie Stores Inc, 1983). Of course, the foregoing comments are a bit simplistic statements since in the "real world" factual causation can be quite complicated as when there is more than one cause or multiple causes of harm or where there are possible intervening, supervening, and/or superseding causes. For example, in the case of Rouse v. George A. Hormel \&Co (1976) the court ruled that the injured plaintiffs failed to prove that the consumption of the defendant packer's luncheon meat, which allegedly contained a sliver of glass, was the cause-in-fact of their illness principally because their illness occurred several hours after they ate the food. Similarly, in the case of Brown v. General Foods Corp (1978) the medical evidence presented by the plaintiff was not sufficient to prove by a preponderance of the evidence that the plaintiff's severe tenderness to the big toe area of the right foot was caused by the ingestion of penicillin fungus which allegedly was growing on a moldy banana peel at the bottom of a box of grape nuts cereal. To compare, in the case of Miller v. Atlantic Bottling Corp (1972) the fact that the showing of harmful symptoms followed shortly after the consumption of the contaminated food was sufficient for the court to allow the case to go to the jury on the issue of a causal connection.

Even if factual causation is determined to be present by the jury, the second causation element - legal or proximate causation - must also be present. Proximate causation is a very interesting and unusual legal doctrine indeed in that it protects careless defendants. The application of the doctrine is within the province of the jury. Even if a defendant acted carelessly and unreasonably and caused harm the defendant is not liable for all the harmful consequences of his or her careless action or omission; rather, pursuant to the proximate causation doctrine a defendant is only liable for the reasonably foreseeable adverse consequences of his or her wrongful act; and as such the careless defendant is not liable for any unforeseeable, unusual, or remote harmful consequences. Thus, if a causation chain is very long and attenuated the jury is allowed, in essence, to "cut off" the causation 
chain, and thus exonerate the defendant from those consequences which the jury has deemed unforeseeable (Keeton et al., 1984; Clarkson et al., 2012; Cavico and Mujtaba, 2014; Cheeseman, 2016). The rationale for the doctrine "is that there be some reasonable connection between the act or omission of the defendant and the damage which the plaintiff has suffered" (Keeton et al., 1984).

Once again, the typical civil "preponderance of the evidence" standard is used to determine if there is a causal connection or relationship between the careless act and the ultimate harm (Way v. Tampa Coca Cola Bottling Co, 1972). Usually, expert testimony in the form of a medical expert will be necessary to establish the causal connection between the illness or injury and the consumption of certain food or beverage, unless the causal connection would be clearly apparent to a jury composed of lay persons based on the circumstances of the case. One court further elaborates that the plaintiff must prove causation to a degree of "reasonable and probable" and the mere existence of a package meat recall will not solely support this burden (Thacker vs. Kroger Company \& ConAgra Inc, 2005). In Thacker, the grocery giant Kroger sold prepackaged meat to the plaintiff which was produced by an independent meat processing company. The appeals court summarized the materials facts as follows:

Sometime in early July, Kristi Thacker purchased ground beef for her family from Kroger's store. All four members of the family ate it during the first two weeks of August. On August 12 and 13, Savana - the youngest member of the family - complained of stomach cramps, and, by August 17, she was vomiting. On August 19, Savana was taken to see her primary physician and then rushed to a hospital where she was diagnosed with Hemolytic Uremic Syndrome (HUS), a disease commonly associated with E. coli. Savana was the only family member that became sick. The Thackers' beef was never tested to confirm the presence of E. coli (Thacker vs. Kroger Company \& ConAgra Inc, 2005).

The Thackers sued Kroger and their meat supplier for negligence after buying processed, packaged meat which they made into hamburgers for their family members to consume, who become ill after eating the same. The United States District Court for the Western District of Missouri granted summary judgment in favor of the defendants, ruling that the plaintiffs failed to establish that the injuries were caused by the beef produced by the meat producer, ConAgra, and sold by Kroger. The appellate court affirmed the trial court's ruling and explained how the plaintiff's lack of causation defeated their negligence claim during the summary judgment phase by explaining:

The Thackers rely mostly on the fact that the beef they ate was subject to the ConAgra/Kroger recall. Additionally, the Thackers interpret Ms. Thacker's testimony to say she bought clear-wrapped ground beef as well as the five-pound chubs. Even assuming Ms. Thacker did purchase clear-wrapped beef, it is undisputed that fresh ground beef has a maximum 18-day shelf life from the date of production. Any meat produced on May 31 - the only production day that the USDA detected E. coli in meat that was actually distributed - would have been removed from the shelves by June 18, long before Ms. Thacker purchased the beef consumed. Thus, viewed most favorably to the Thackers, the clear-wrapped beef, while subject to the recall, was not part of the contaminated meat discovered by the USDA on May 31 . This fact does not establish the causation necessary to avoid summary judgment....Finally, to the extent there is more than one possible cause of Savana's HUS, the Thackers fail to show by substantial evidence the probable cause (Thacker vs. Kroger Company \& ConAgra Inc, 2005).

Further, the plaintiff's own medical expert, a medical doctor, could not affirmatively state with any medical certainty the cause of the food that injured the plaintiffs and his testimony was characterized by the appeals court as speculative. In granting summary judgment in favor of the grocery store and meat processing supplier, the appeals court pointed out Missouri's long standing principle, to wit: "Where there are multiple possible causes, the plaintiff must exclude other causes by presenting substantial evidence that a particular cause for which defendant is liable is responsible for plaintiff's injuries" (Thacker vs. Kroger Company \& ConAgra Inc, 2005).

\section{Damages}

The final element in a cause of action for negligence is the presence of damages. An actual loss or harm to the person or interests of the person is required. Nominal, that is, token, damages are insufficient as are damages for the threat of any future harm. Actual damages can include harm to the person, medical costs and expenses, lost wages, damage to his or her property - real or personal, or economic harm. Moreover, since negligence is a tort as per the common law damages can include emotional distress and "pain and suffering" at the discretion of the jury. Finally, if the negligence is deemed by the jury to be "gross," that is, flagrant, or reckless, then the jury can impose at its discretion punitive damages as punishment and as a deterrent (Keeton et al., 1984; Clarkson et al., 2012; Cavico and Mujtaba, 2014; Cheeseman, 2016).

One problem for an injured consumer who wants to sue for emotional distress damages based on negligent conduct is the traditional "impact" rule of negligence law which maintains that one has to be physically impacted, at least touched, in order to sustain an emotional damage recovery for the negligent conduct (Cavico and Mujtaba, 2014; Cheeseman, 2016). This rule could be a problem in a food or beverage negligence case in some states when the consumer does not ingest a portion of the contaminated food or is not harmed by the object in the food. For example, in Doyle v. Pillsbury Co. in 1985 the plaintiff consumer alleged that she opened a can of peas, saw an insect floating in the can, was frightened, fell backwards over her chair, and suffered emotional distress; however, the Florida Supreme Court denied recovery because the plaintiff did not consume the adulterated food and thus she was not "impacted." Ingestion of the food, therefore, was required by the court. Similarly, if a customer sees hair in his or her food but does not eat the food, the customer may be "grossed out" and thus loudly complain to the staff and management, but the customer likely will not be able to sue for emotional distress because of the lack of an impact. However, if the consumer does ingest the food or beverage, for example, tasting a flat soda and then seeing an apparent used condom in it, the consumer, who became nauseated and went to a health facility to be vaccinated, and then was tested twice for HIV-AIDS, could sue for the emotional harm caused, according to the Florida Supreme Court (Hagan v. Coca-Cola Bottling Co, 2001). Note, though, that some courts have attempted to liberalize the older "impact" rule in food cases by saying that the consumer has to either ingest the food (i.e., the 
“impact”) or suffer objective physical systems in response to the foreign substance (Way v. Tampa Coca Cola Bottling Co, 1972).

\section{The Doctrine of Res Ipsa Loquitur}

When an injured plaintiff lacks direct evidence that the defendant breached the duty of care, the plaintiff may be able to use the doctrine of res ipsa loquitur ("the thing speaks for itself") to create an inference or presumption of negligence. This presumption is a rebuttable one, it must be emphasized. The injured plaintiff will have to show that the defendant had control of the situation that caused the harm to the plaintiff. The plaintiff also will still have to show that it was more likely than not that the defendant caused the plaintiff's injury (Keeton et al., 1984; Clarkson et al., 2012; Cavico and Mujtaba, 2014; Cheeseman, 2016). Moreover, the plaintiff will still have to demonstrate the causation and damages elements of a negligence lawsuit. A favorable granting of a res ipsa loquitur request will allow the injured consumer to proceed with circumstantial evidence, primarily the fact of the injury itself and the unusualness of its occurrence (Keeton et al., 1984; Clarkson et al., 2012; Cavico and Mujtaba, 2014; Cheeseman, 2016).

Courts typically will require a three-part test to determine if res ipsa loquitur is applicable to a case, to wit: 1) the injury or harm was caused by an agency or instrumentality under the exclusive control of the defendant; 2) the injury or harm must be of a type that ordinarily does not occur unless someone was negligent; and 3) the injury or harm must not have been due to any voluntary act or contributing fault of the injured plaintiff (Keeton et al., 1984; Benton, 2012; Clarkson et al., 2012; Cavico and Mujtaba, 2014; Lipp and Hafer, 2014). For example, in Ford v. Miller Meat Company (1994) the injured plaintiff brought a lawsuit against a supermarket and meat supplier for negligence utilizing res ipsa loquitur when she broke a tooth when she bit into a bone fragment in ground beef she had purchased. Similarly, in Schafer v. JLC Food Systems Inc (2005) the injured plaintiff utilized res ipsa loquitur to recover for a throat injury caused by a defective pumpkin muffin.

As Benton (2012) points out, the "exclusive control" element could present a huge challenge to the injured consumer in foodborne illness cases since based on a particular state's law the plaintiff may have to exclude all other reasonable possibilities of his or her illness. That is, evidence is required for a jury to make an inference that the contamination or other unsafe aspect of the food or beverage product came from a particular defendant's lack of due care (Benton, 2012; Lipp and Hafer, 2014). For example, in Burnett v. Essex Insurance Company (2000)the plaintiffs who suffered abdominal problems allegedly from bacteria in food did not prevail because their physician could not eliminate other possible causes of illness, such as the local drinking water or that one of the plaintiffs was susceptible to gastric disorders.

\section{Negligence Per Se}

A duty of due care may also be specifically created by a statute or government regulation. As such, the violation of a statute with such a duty which contravention causes injury to a party is called "negligence per se." The injured plaintiff would have to prove that such a statute existed, it was promulgated to protect against the type of harm suffered, and the injured plaintiff was within a class of people to be protected by the statute (Keeton et al., 1984; Clarkson et al., 2012; Cavico and Mujtaba, 2014; Cheeseman, 2016). For example, in the case of Coward v. Borden Foods (1976) the fact that there was proof of a violation of the Food and Drug Act could constitute negligence per se if the violation factually and proximately caused the injury to the plaintiff. One court has held that a negligence per se cause of action against food manufacturers must be based upon the alleged violation of a statute and cannot be premised upon the violation of a regulation (Cohen v. Fairbank Reconstruction Corporation d/b/a Fairbank Farms, 2012). While both have the effect of law, statutes are bills passed by state legislatures or the federal Congress and signed by the state governor or the president of the United States, while a regulation is promulgated by an administrative agency with at least a public notice and comment procedure.

There are, obviously, many statutes and regulations regarding food and beverage safety. To cite one recent enactment, in 2011, President Obama signed the Food Safety and Modernization Act (FSMA), which Congressional statute seeks to improve the nation's food safety by empowering the Food and Drug Administration (FDA) to further and more effectively regulate food and beverages by promulgating, overseeing, and enforcing food safety regulations (Benton, 2012). One important provision of the FSMA grants the FDA the authority to recall food products if the agency determines that there is a "reasonable probability" that an article of food or beverage is adulterated or mislabeled and the use or exposure will cause adverse health consequences to humans or animals Benton (2012). The FMSA dos not provide a private cause of action for damages based on an FDA food recall. However, Benton (2012) points out that critics of the statute are concerned that “reasonable probability' is not a stringent enough standard and that when combined with a mandatory recall will be seen as proof that food is dangerous, encouraging the filing of successful lawsuits." That is, the fact of the food recall may be argued as evidence that the standard of care was breached for a negligence lawsuit, the food is not merchantable for a warranty lawsuit, and/or the food is "defective" for a products liability lawsuit. However, in the case of Velazquez v. Abbott Labs (2012) the plaintiff's parents alleged that their infant suffered acute gastroenteritis as a result of ingesting defendant manufacturer's powdered milk. The defendant was entitled to summary judgment on strict liability and negligence claims because defendant's recall notice and the FDA's notices about the recall were inadmissible to show that the milk ingested by the infant contained beetles, there was insufficient evidence to establish that there was a defect in the powdered milk and that the powdered milk caused the infant's illness, and the plaintiffs did not show that defendant breached any standard of care (Velazquez v. Abbott Labs, 2012).

\section{Defenses}

Contributory negligence and comparative negligence are defenses to a negligence lawsuit which are based on the law of each state (Keeton et al., 1984; Clarkson et al., 2012; Cavico and Mujtaba, 2014; Cheeseman, 2016). The former holds that a plaintiff who is even partially responsible for his or her own injury cannot recover anything from a defendant; and in the latter a jury is allowed to apportion the fault to each party and then to deduct that percentage of fault from the plaintiff's recovery (Keeton et al., 1984; Cavico and Mujtaba, 2014; Cheeseman, 2016). 
Food and beverage examples would be when the plaintiff caused his or her own illness through his or her own negligent conduct by the careless storage or preparation of a food or beverage product. One illustration of an assertion of comparative negligence is the Florida Court of Appeals case of Coulterv v. American Bakeries Company (1988) where the consumer, who had an abscessed tooth, dissolved a donut in milk, and while drinking the milk through a straw, had a piece of wire which was in the donut lodged in her throat; but the court ruled that she was not comparatively negligent under the circumstances for not chewing the donut.

Another example of a defense would be assumption of the risk, where the plaintiff knowingly and voluntarily assumes a known risk or danger that a reasonable person would not. Assumption of the risk is a complete defense to a negligence lawsuit (Keeton et al., 1984; Clarkson et al., 2012; Cavico and Mujtaba, 2014; Cheeseman, 2016). So, for example, if one continues to eat food with known foreign fragments in it and is injured thereby it can be said that one assumed the risk of injury. Segal (2006) even posits that assumption of the risk could be used in eating improperly, to wit: "Eating in excess or consuming food that is high in fat can obviously cause health problems for consumers, especially children who are part of the fast-food revolution."

\section{B. Warranty Law and the Uniform Commercial Code \\ 1. Article 2 of the Uniform Commercial Code}

Warranty law is based on the Uniform Commercial Code (UCC) which is a statutory law adopted by all the states in a (more-or-less) uniform manner. A warranty is a guaranty that a seller makes about its goods when making a sale. Generally, the warranty means that the goods will operate in a certain way or conform to a certain standard. By making the warranty the seller agrees to compensate the buyer for any loss or damages suffered if the goods are not as warranted. Warranties can be express, that is, by affirmative words, action, or conduct of the seller, or implied, that is, implied by the law (the UCC). There are warranties of title and warranties of title (Clarkson et al., 2012; Cavico and Mujtaba, 2014; Cheeseman, 2016). For the purposes of this article the authors examine the three UCC implied warranties of quality - the implied warranty of merchantability, the implied warranty of wholesomeness, and the implied warranty of fitness for a particular purpose. First however, the sale of a good requirement, which is an indispensable feature of the UCC, must be explicated.

\section{The Sale of a Good Requirement}

Warranty law, as noted, is based on the UCC, which is premised on the sale of a "good." There thus must be the sale of a good for UCC warranty law to be applied. Goods are tangible, physical, personal property. Food and beverages certainly are goods. Employment relationships and the provision of services of course may be based on contracts but they are not "goods" and thus no implied warranties would arise. There may be breach of contract lawsuits as well as negligence lawsuits in employment and service situations, but not UCC breach of warranty lawsuits (Clarkson et al., 2012; Cavico and Mujtaba, 2014; Cheeseman, 2016).

\section{Implied Warranties - Generally}

As noted, the law by virtue of the UCC implies certain warranties just because a sale of goods is made. It is important to point out that these warranties are imposed by the law regardless of the seller's intentions and regardless of the fact that the seller has not made any representations, statements, or promises regarding the goods. Unless the warranties are disclaimed by the seller they arise by operation of the UCC in every sale of a good (Cavico and Mujtaba, 2014; Cheeseman, 2016). However, as to the warranty liability of cruise line companies, it should be noted that this area of the law is governed primarily by admiralty law; and as such one federal district court stated that it was unwilling to imply a UCC warranty of merchantability against a cruise line being sued by a passenger who contracted food poisoning requiring surgery since the admiralty courts would have primary jurisdiction (Bird v. Celebrity Cruise Lines, 2005).

If genuine issues of fact are in dispute in either breach of implied warranties of merchantability or fitness for a particular purpose claims, a plaintiff's allegations will proceed to trial against both a producer of a food product and the supermarket seller. For example, in L.W. v. Tyson Foods Inc. \& Wal-Mart Stores East L.P (2011) both the plaintiff and defendants produced evidence disputing where the contaminated meat products were bought and the causation of the resulting food poisoning of the child who consumed the meat. In that case, L.W., a minor child, consumed a hamburger at his grandmother's house. She prepared the hamburger allegedly from Tyson's ground beef she bought at the Wal-Mart. The child shortly thereafter, became ill with diarrhea, nausea, vomiting, fever, and stomach cramps and eventually hospitalized and diagnosed with campylobacter food poisoning. Subsequently, the parents filed the action on the child's behalf alleging breach of the implied warranties of merchantability and fitness for a particular purposes against both the manufacturer of the meat, Tyson Foods, and the supermarket retailer which sold the meat, Wal-Mart. The defendants disputed the facts that the food product was purchased at Wal-Mart and that the meat was contaminated. The plaintiff contended that they bought the meat from Wal-Mart and furthermore, another relative became ill also after eating the same meat. Given these disputed facts, the court held that the jury was best to resolve these disputes.

\section{The Implied Warranty of Merchantability}

The Uniform Commercial Code in Section 2-314 maintains that a warranty that goods sold by merchant must be "merchantable" will be imposed in a contract for the sale of the goods. In order to be of "merchantable" quality the UCC specifies several criteria, to wit: the goods must be fit for the ordinary purposes for which the goods are used; the goods must meet normal commercial standards; the goods must do their ordinary job safely; the goods must be of the middle range of quality; and the goods must be adequately packaged and labeled (Clarkson et al., 2012; Cavico and Mujtaba, 2014; Cheeseman, 2016). It is very important to note that only "merchants" are deemed to make the implied warranty merchantability. The merchant must also be a merchant with respect to the goods sold; as such, sales by merchants out of their field or by private individuals are not governed by the UCC merchantability warranty (Clarkson et al., 2012; Cavico and Mujtaba, 2014; Cheeseman, 2016). For the purposes herein, manufacturers, wholesalers, distributors of food and beverages, retailers such as supermarkets and grocers, 
as well as restaurants, can be deemed to be merchants. Courts look for guidance in determining the "merchantability" of food and beverages from applicable government regulatory standards, court precedents, characteristics of the same or similar goods produced by others, and usages in the trade (Eller, 1993). The burden of proof and persuasion is on the injured consumer to prove that the food was not merchantable (Deveraux $\mathrm{v}$. McGarry's Inc, 1970).

There are times when the implied warranty of merchantability may validly state a claim against a food manufacturer but not the grocery retailer of the same product. A good example of this is in the case of Porrazzo v. Bubble Bee Foods LLC \& The Stop and Shop Supermarket Company LLC (2011) where the plaintiff sued both the manufacturer of the canned tuna fish and the supermarket that sold the same product. The plaintiff's amended complaint alleged the following fact pattern:

Plaintiff Lee Porrazzo consumed approximately ten six-ounce cans of tuna fish per week from approximately January 2006 to October 2008. The tuna fish was canned by Defendant Bumble Bee Foods, LLC ("Bumble Bee"). Plaintiff purchased this tuna fish, which was frequently on sale, from Defendant Stop \& Shop Supermarket Company ("Stop \& Shop"). During this time Bumble Bee promoted its tuna fish as an "excellent and safe source of high quality protein, vitamins, minerals and Omega-3 fatty acids, as well as being low in saturated fats and carbohydrates [,] and touted its product as being 'heart healthy."' The Bumble Bee tuna fish did not provide any warning that it contained mercury, "an odorless, colorless, tasteless, poisonous, heavy metal."

At some point between January 2006 and October 2008, Plaintiff began to experience, two to three times per week, "episodes of chest pains, heart palpitations, sweatiness, dizziness, and lightheadedness," which led him to believe that he had a heart condition. Plaintiff sought medical attention and underwent numerous tests to understand the cause of his symptoms, but none of these tests provided an answer. On April 14, 2006, Plaintiff went to the White Plains Hospital Emergency Room because he believed (incorrectly) that he was having a heart attack.

On or about October 1, 2008, Plaintiff's primary care practitioner ordered a heavy metals blood test, which showed that there was an elevated level of mercury in Plaintiff's blood. Specifically, Plaintiff's blood mercury level was $23 \mathrm{mcg} / \mathrm{L}$ as opposed to the less than $10 \mathrm{mcg} / \mathrm{L}$, which is normal. On the same date, the New York State Department of Health contacted Plaintiff by telephone, advised him that he had a dangerous level of mercury in his blood, asked him questions, filled out a questionnaire, and instructed him to stop eating tuna fish. Plaintiff stopped eating tuna fish, and a blood test on November 4, 2008, revealed that his mercury levels had returned to normal. Plaintiff no longer suffered the heart attack-like symptoms previously described, but he alleges that he "remains worried today about what effects the mercury has had on his health" (Porrazzo v. Bubble Bee Foods LLC \& The Stop and Shop Supermarket Company LLC, 2011 ).

Both Bubble Bee and the Supermarket moved to dismiss the amended complaint for failure to state a cause of action under the theory of breach of warranty of merchantability. The court ultimately held that this plaintiff's implied warranty claim against Bubble Bee, the tuna manufacturer, could survive a motion to dismiss, by explaining:

The relevant question here, therefore, is whether the presence of mercury in Defendants' canned tuna, without any accompanying warnings, renders it not reasonably fit for the ordinary purpose for which it was intended. In other words, Plaintiff's claim for breach of implied warranty turns upon whether: 1) the customary, usual, and reasonably foreseeable use of tuna fish includes the type of consumption Plaintiff engaged in--namely, eating approximately one to two cans of tuna fish daily for more than two years; and 2) Plaintiff reasonably expected mercury--which, when consumed in those quantities, could be poisonous-to be present in the fish......at this stage Plaintiff has plausibly alleged as much. (The Court on summary judgment or a jury could, of course, conclude otherwise.) Furthermore, Plaintiff's ability to recover under his breach of implied warranty claim is not affected by the feasibility of making the product safer, and thus whether mercury is naturally present in tuna and/or can be removed through the use of ordinary care is irrelevant. Because Plaintiff plausibly alleges that he was, indeed, "injured by conditions which he could not have reasonably anticipated to be present in the product purchased," [citing case precedent] Defendants' motion to dismiss Plaintiff's claim for breach of the implied warranty of merchantability as to Bumble Bee is denied (Porrazzo v. Bubble Bee Foods LLC \& The Stop and Shop Supermarket Company LLC, 2011).

However, as to the Supermarket retailer defendant, which sold the same alleged defective tuna fish to the plaintiff, the breach of implied warrant of merchantability claim could not survive a motion to dismiss. The court explained the application of that theory of recovery against a grocer as follows:

With respect to Plaintiff's claim for breach of implied warranty of merchantability against Stop \& Shop (Count II), however, such claim must fail. For claims for breach of warranty and negligence, a retailer 'cannot be held liable for injuries sustained from the contents of a sealed product even though a test might have disclosed a potential danger' because ' $t$ )here is no obligation upon it to make such a test' (citing case precedent). Because Stop \& Shop is a retail seller that cannot be held liable under breach of warranty for a defect it could not discover through ordinary inspection, Defendants' motion to dismiss Count II, as to a breach of implied warranty, is granted (Porrazzo v. Bubble Bee Foods LLC \& The Stop and Shop Supermarket Company LLC, 2011 ).

\section{The Implied Warranty of Wholesomeness}

Regarding food and beverage products, the UCC's implied warranty of wholesomeness maintains that food and beverages must be "fit for human consumption." The warranty is imposed by law by virtue of the UCC. If food or beverages are unwholesome, that is, poisonous, noxious, contaminated, adulterated, or otherwise unfit for human consumption, the products are of course not "merchantable." The warranty applies to retailer supermarkets and grocers whether the items are selected by the grocer for the customer or selected by the customer from the shelf or when the products come prepackaged in sealed containers. The warranty is also implied against restaurants regardless of whether the food is sold for consumption on-or-off the premises (Clarkson et al., 2012; Cavico and 
Mujtaba, 2014; Cheeseman, 2016). The warranty also applies fast-food restaurants, coffee shops, bars, vending machines, and other sellers of food and beverages (Cheeseman, 2016). A problem, however, arises with the wholesomeness warranty when there is an object in the food or beverage, which problem area is covered in the next sub-section to this article.

\section{The Foreign/Natural Test v. the Reasonable Expectations Test}

The legal and practical problem regarding food and beverages and wholesomeness arises when there is an object in the product that injures the consumer. The courts have used two tests to determine liability for objects in food and/or beverages - the older "foreign/natural" test and the newer "reasonable expectations" of the consumer test (Clarkson et al., 2012; Cavico and Mujtaba, 2014; Cheeseman, 2016). The foreign/natural test harkens back to a California Supreme Court decision in 1936, wherein the court said in a case involving a chicken bone fragment in a chicken pie that liability would only be imposed under products liability law if food was impure or noxious or if there was a foreign substance in the food, such as glass, metal, or a creature; but since a chicken bone is "natural" to chicken food there would be no liability for any harm caused (Mix v. Ingersoll Candy Co, 1936).

However, under the "reasonable expectations" test, first, if the object in the food or beverage is "foreign" there is legal liability as there was under the foreign/natural test. However, in a major change to this area of wholesomeness warranty law, if the object is "natural," recovery by the injured plaintiff would be permitted if he or she could demonstrate that the object or substance in the food or beverage was one that a reasonable consumer would not expect or anticipate (Goodman v. Wenco Foods Inc, 1992; Clarkson et al., 2012; Cavico and Mujtaba, 2014; Cheeseman, 2016). Eller (1993) explains the rationale for the "reasonable expectations" test, to wit: “...If a consumer does not reasonably expect the substance to be present in the food, he cannot take precautions to avoid being injured by it; the food is thus unfit for consumption because it cannot be eaten without risk of injury." The North Carolina Supreme Court in the 1992 decision of Goodman v. Wenco Foods Inc (1992) which involved a consumer suffering severe dental injuries by biting into a hamburger sold by a fast-food establishment due to a "natural" meat bone fragment in the food, overruled the appeals court which applied the foreign/natural test to deny recovery; rather, the state Supreme Court adopted the "reasonable expectations" test, thereby allowing the case to go to a jury. Also, in Jackson v. Nestle-Beich, 1992), the Supreme Court of Illinois, in a case involving a pecan shell in chocolate-covered pecan candy, rejected the "foreign-natural" test and thus changed that state's law to the "reasonable expectations" test.

To compare, in the state Supreme Court 1964 decision by the Massachusetts Supreme Court in Webster v. Blue Ship Tea Room, Inc., the court held that a reasonable consumer should expect fish bones in a bowl of New England fish chowder, and thus there was no breach of the merchantability warranty. Similarly, a Florida appeals court ruled that it was reasonable to expect an occasional piece of clam shell in a bowl of clam chowder and thus the manufacturer of the chowder and the supermarket which sold it were not liable (Koperwas v. Publix Supermarkets Inc, 1988). Other examples of both tests are provided by Cheeseman (2016) to wit:

Under the foreign substance test, “...the implied warranty would be breached if a person were injured by eating a nail in a cherry pie. This is because a nail is a foreign object in cherry pie. The implied warranty would not be breached if a person were injured by eating a cherry pit in the pie. This is because the cherry pit is not a foreign object in the cherry pie....Under the (consumer expectation test), the implied warranty would be breached if a person would be injured by a chicken bone while eating a chicken salad sandwich. This is because the consumer would expect that the food preparer would have removed all bones from the chicken. Under this test the implied warranty would not be breached if a person were injured by a chicken bone while eating fried chicken. This is because a consumer would expect to find bones in fried chicken ( $p$. $361)$.

As to which test is applied in a particular jurisdiction one would need to make reference to pertinent state law. However, Bassett et al. (2009) in examining Texas law, conclude that “...the trend appears to be that if a case were in a gray area, the courts would tend to choose the reasonable expectation test, which involves determining what is reasonably expected by the consumer in the food served. However, as it has been in the past, if the foreign object is clearly 'foreign,' formal adoption of any one doctrine would not be necessary, because liability would attach due to the product being unfit for human consumption." Finally, it must be pointed out that the ultimate decision-maker as to the reasonableness of the consumer's expectations typically would be a jury.

Both the manufacture and supermarket defendants' in Porrazzo v. Bubble Bee Foods LLC \& The Stop and Shop Supermarket Company LLC (2011) attempted to escape liability from alleged mercury within canned tuna by using the reasonable expectation and obviousness of danger of the presence of this substance in tuna. The judge rejected that premise at the motion to dismiss phase of the case by explaining:

In order to succeed on either a failure to warn claim, or a breach of implied warranty claim, a plaintiff must also establish that the danger inherent in the injurious product was not open and obvious and thus something which a reasonable consumer would ordinarily anticipate finding therein. This is not a case where I can say as a matter of law at this stage that the dangers of mercury poisoning from consumption of canned tuna fish are open and obvious, and that an ordinary consumer would necessarily be aware that canned tuna fish contains high levels of methylmercury, the consumption of which could lead to mercury poisoning. This is particularly so because mercury is "an odorless, colorless, tasteless," metal, and thus nothing about the appearance of the fish itself would reveal either that it contains mercury or that such mercury may be dangerous if consumed on a daily basis. There may be many consumers who are unaware that canned tuna fish--which they believe is a low-fat, heart-healthy, source of protein--in fact contains mercury which can, in high quantities, be harmful to their health. Thus, although the facts as developed may permit the conclusion, by the Court on summary judgment or by the jury at trial, that consumers do reasonably expect mercury in their tuna and understand that it can be harmful, the allegations of the Amended Complaint do not support such a conclusion, and it is not obvious to the Court as a matter of judicial experience and common sense (Porrazzo v. Bubble Bee Foods LLC \& The Stop and Shop Supermarket Company LLC, 2011). 
Both defendants also argued that the plaintiff acted unreasonably when consuming so much tuna and thus requested the amended complaint to be dismissed. The court also rejected this line of reasoning and allowed the case to proceed forward by explaining:

Defendants contend that Plaintiff's consumption of its canned tuna fish was unreasonable as a matter of law and that Plaintiff's claims therefore cannot survive. (See Defs.' Mem. at 22 ("[A] diet consisting of nearly 1,500 cans or over $500 \mathrm{lbs}$ of tuna in thirty-three months is undisputedly outside the 'intended use' of the product").) Defendants' contention is unavailing. Plaintiff's daily consumption of one to two cans of tuna fish cannot, as a matter of law at this stage, be said to be unreasonable. ${ }^{9}$ Indeed, Plaintiff was arguably exactly the type of consumer that Defendants desired--a consumer who purchased and consumed their product regularly. Moreover, even if Plaintiff's consumption of such quantities of tuna was unreasonable, Defendants still would be liable for failure to warn if Plaintiff's conduct was foreseeable (Porrazzo v. Bubble Bee Foods LLC \& The Stop and Shop Supermarket Company LLC, 2011).

\section{The Implied Warranty of Fitness for a Particular Purpose}

The implied warranty of fitness for a particular purpose arises when a seller is aware of a particular use of goods by a buyer and the buyer relies on the seller's knowledge and judgment to select suitable goods. One need not be a merchant to have this warranty arise; rather the seller must know of the buyer's special requirements and that the buyer is relying on the seller to fulfill these requirements (Clarkson et al., 2012; Cavico and Mujtaba, 2014; Cheeseman, 2016). However, if the sale is made according to buyer's specifications, for example, perhaps, specialized food items ordered by the buyer to the buyer's specifications, the warranty does not arise because the buyer cannot claim reliance on the seller's selection of the goods (Clarkson et al., 2012; Cavico and Mujtaba, 2014; Cheeseman, 2016).

In a 2017 Missouri "fitness" case, the defendant Vaughan Foods, Inc., sold romaine lettuce to Schnuck Markets, Inc. Vaughan was aware that the lettuce would be sold to the public for human consumption; it would be placed in Schnuck salad bars in numerous locations. The plaintiff (an insurance company representing Schnuck) claimed that romaine lettuce that had been provided by Vaughan to Schnuck around 2011 or 2012 had been contaminated with Ecoli and thus caused illness to many people who ate at Schnuck salad bars. The plaintiff brought suit against Vaughan as well as C\&E Farms, Inc., which had supplied Vaughan with romaine lettuce from its farms. The suit included various claims, including breach of implied warranty of fitness for a particular purpose (Chartis Specialty Ins. Co. v. Vaughan Foods Inc, 2017).

Vaughan filed a motion to dismiss, asserting that the claim for breach of implied warranty for a particular purpose was invalid because the lettuce had been used for its normal and ordinary purpose, human consumption for salads, rather than for any particular purpose. In contrast, the plaintiff argued that the lettuce had been used for the particular purpose of being sold in a raw, unprepared state in Schnuck salad bars (Chartis Specialty Ins. Co. v. Vaughan Foods Inc, 2017). The court explained,

A claim for breach of implied warranty of fitness for a particular purpose exists: “[w] here the seller at the time of contracting has reason to know any particular purpose for which the goods are required and that the buyer is relying on the seller's skill or judgment to select or furnish suitable goods there is unless excluded or modified under section 400.2-316 an implied warranty that the goods shall be fit for such purpose." (quotations added) (Id., pp. 4, 5 (quoting Mo. Rev. Stat. $§ 400.2-315$ )).

The court went on to clarify that a "particular purpose" is different from the ordinary purpose for which the goods are used in that a particular purpose envisages a specific use by the buyer which is peculiar to the nature of his/her business (Mo. Rev. Stat. $\$ 400.2-315$, at comment 2). Thus, "when deciding whether a product has been used for a unique purpose, the crucial question is not whether anyone else uses the goods in the same way, but whether the buyer's use is sufficiently different from the customary use of the goods to make it not an ordinary use of the goods" (Chartis Specialty Ins. Co. v. Vaughan Foods Inc, 2017).

With regard to this case, the court noted that lettuce is ordinarily sold in its raw form and consumed in salads (and that nothing in the plaintiff's arguments had stated otherwise). Moreover, while "Plaintiff attempts to convert the use of lettuce to something unique by virtue of its sale in Schnucks' salad bars, the Court finds that the location does not alter the ordinary use of the lettuce, which is sold in its raw state and consumed in salads" (Chartis Specialty Ins. Co. v. Vaughan Foods Inc, 2017). Accordingly, the court dismissed the claim of breach of implied warranty for a particular purpose.

\section{The Privity and Notice Requirements}

The concept of privity is a difficult area of warranty law, especially for the injured consumer. Originally, pursuant to the UCC privity meant the requirement that an actual contractual relationship existed between the seller and buyer of the goods. Consequently, only the actual buyer could sue for breach of warranty and he or she could sue only the immediate seller of the goods. Today the privity doctrine has been modified or abolished in many states (Clarkson et al., 2012; Cavico and Mujtaba, 2014; Cheeseman, 2016). An examination of privity is beyond the scope of this article; nonetheless, the authors warn that depending on state law privity may emerge as an impediment to UCC warranty recovery. Notice is another technical requirement of the UCC, and yet another problem for the injured consumer, as the UCC holds that in order to recover for breach of warranty the buyer must give the seller notice of the breach within a reasonable time after the breach has been discovered (Clarkson et al., 2012; Cavico and Mujtaba, 2014; Cheeseman, 2016). Like privity, the states have made modifications to this strict notice requirement; and again, any detailed examination is beyond the purposes of this article; nevertheless, the authors also extend the same warning to be aware of any privity and notice requirements still in existence in a particular state's law.

\section{Disclaimers}

Another major problem for consumers with warranty law is that the UCC permits sellers of goods to exclude implied warranties from the sales transaction. By means of a disclaimer the seller can lawfully exclude 
warranties from the sales transaction. Of course, the consumer can still sue for negligence and, as will be seen, for strict liability. For a disclaimer to be operative the UCC says that it must be "conspicuous," that is, a reasonable person should be aware of it, thereby obviating any "fine-print" disclaimers. Also, for a seller to disclaim merchantability the exact word "merchantability" must be used; and to disclaim fitness the disclaimer must be in writing. Finally, "catch-all” disclaimers, such as buyer takes the goods "as-is," in their "present condition,” or "as they stand" will exclude all implied warranties, presuming these disclaimers are conspicuous (Clarkson et al., 2012; Cavico and Mujtaba, 2014; Cheeseman, 2016).

\section{Damages}

If the injured consumer can show a sale, a warranty, the goods do not conform to the warranty, and the plaintiff consumer was injured he or she can sue for breach of warranty and recover the following damages: any loss of value in the goods, consequential damages (that is, other damages reasonably foreseeable from the breach of warranty), personal injury damages, including pain and suffering, property damages, and any other incidental damages (such as storage or inspection fees) (Clarkson et al., 2012; Cavico and Mujtaba, 2014; Cheeseman, 2016).

\section{Strict Liability in Tort}

\section{Definition and Core Principles}

In addition to negligence law and warranty law products liability law encompasses a relatively new, significant, frequently asserted, and very pro-consumer doctrine - strict liability in tort for defective products. Strict liability comes from the Restatement (Second) of Torts, Section 402A. A "Restatement" is a compendium of law developed by legal scholars offered to the courts for adoption. Restatements are regarded as authoritative legal authority; but they are not case law precedents. So, as a case precedent, the strict liability doctrine was first enunciated by the California Supreme Court in the famous 1963 case of Greenman v. Yuba Power products. It is thus a state common law doctrine which has been adopted by all the states in the United States (Clarkson et al., 2012; Cavico and Mujtaba, 2014; Cheeseman, 2016). Pursuant to strict liability one who sells a product in a defective condition unreasonably dangerous to the consumer or user is liable if 1) the seller is engaged in the business of selling such a product; and 2) the product is expected to and does reach the consumer or user without substantial change in the condition which it is sold (Keeton et al., 1984; Clarkson et al., 2012; Cavico and Mujtaba, 2014; Cheeseman, 2016). Strict liability is thus "strict," that is, fault is imputed to the seller even though the seller has exercised all possible care in the preparation and sale of the product. As such, an absence of negligence will not preclude liability (Clarkson et al., 2012; Cavico and Mujtaba, 2014; Cheeseman, 2016). Moreover, strict liability applies even though the consumer or user has not purchased the product from, or entered into any contract with, the seller (Clarkson et al., 2012; Cavico and Mujtaba, 2014; Cheeseman, 2016). As emphasized, strict liability as fashioned by the California Supreme Court is a very pro-consumer doctrine that has many advantages to the injured user or consumer, to wit: 1) there is no need to prove that a defect in the product that caused harm was caused by the negligence of the seller; 2 ) there is no need to prove that any warranty existed; 3) the injured party need only prove that the goods were dangerously defective when the goods left the seller's hands and the defect caused the injury; 4) any privity and notice requirements under warranty law are eliminated; 5) similarly disclaimers are not effective; and, finally, not only the manufacturer, but also wholesalers, distributors, retailers, and any vendors of food are liable (Bassett et al., 2009; Clarkson et al., 2012; Cavico and Mujtaba, 2014; Cheeseman, 2016). Moreover, the parties "below" the manufacturer on the marking chain are liable even if the product came to them in sealed package or container from the manufacturer (Cavico and Mujtaba, 2014; Cheeseman, 2016). Moreover, Section $4012 \mathrm{~A}$ of the Restatement (Second) of Torts (1979) in Comment i maintains that a seller of a good is strictly liable for any condition not contemplated by the ultimate consumer that renders the product unreasonably dangerous to the consumer, thereby creating, in essence, a "reasonable expectations" test in strict liability law which of course can be applied to food (Getz, 1994; Cousineau, 2010). Finally, there is a Restatement (Third) of Torts: Products Liability (1997) which provides some food liability examples in the context of strict liability, as will be seen.

The objectives of strict liability are to promote safety, to make sure the injured party is compensated for his or her injuries, and to motivate the sellers of products to obtain insurance (Clarkson et al., 2012; Cavico and Mujtaba, 2014; Cheeseman, 2016). In the context herein the parties on the food chain would be advised to purchase food safety liability insurance (Cogan, 2016). Yet, despite the pro-consumer bias to the doctrine, strict liability is not an absolute liability type of law. For there to be liability the product must be defective and unreasonably dangerous. However, most courts will assume the "unreasonably dangerous" aspect of the doctrine if the product is defective (Clarkson et al., 2012; Cavico and Mujtaba, 2014; Cheeseman, 2016). Accordingly, finding the "defect" in the product is the key to liability. A product can be defective in three ways: 1) it is flawed; 2) it lacks an adequate warning; or 3) the product is defectively designed.

\section{Nature of a "Defect"}

\section{a. Flawed Products}

The failure of a manufacturer to adhere to its own manufacturing standards will result in a product being deemed "flawed" and thus defective (Keeton et al., 1984; Clarkson et al., 2012; Cavico and Mujtaba, 2014; Cheeseman, 2016). As emphasized, this is not a negligence action; no evidence is required as to how and why the standards were not complied with; rather, the injured party "simply" compares the product (or what is left of it) to the manufacturer's own standards for that product; and if the latter were not followed the product is flawed (Keeton et al., 1984; Clarkson et al., 2012; Cavico and Mujtaba, 2014; Cheeseman, 2016). Of course, expert testimony will likely be required for that comparison. Accordingly, in a food or beverage case involving an adulterated or contaminated product or an object in a product the injured consumer would have to show that the manufacturer violated its own rules, regulations, standards, and/or procedures in making, storing, preparing, or serving the product. For example, in the case of Wachtel v. Rosol (1970) an egg salad sandwich was deemed defective and unreasonably dangerous because it contained salmonella. 
In Sec Nat'l Bank v. Abbott Labs (2013) the plaintiff claimed that the infant formula manufactured by Abbott had deviated from the formula's intended design due to the presence of E. sakazakii (a bacteria). In support of its claim, the defendant cited another court's decision in which Abbott was the Defendant under similar facts - Burks $v$. Abbot Laboratories (639 F. Supp. 2d 1006, 1016). In that case, the court found that because the infant formula is a non-sterile product and is expected to be contaminated, the plaintiff failed to show that Abbott's product deviated from its intended design. However, the court here disagreed, explaining that "this court does not think that the presence of harmful bacteria in baby formula is "expected" by the average, reasonable consumer" (Sec Nat'l Bank v. Abbott Labs, 2013).

In its analysis, the court explained that the other court's decision appeared to depend on the fact that the FDA had reported in 2003 that E. sakazakii was present in $23 \%$ of this type of formula according to tests, making such presence somehow common knowledge or acceptable. Likewise, in this case, the defendant had argued that,

the general rule that a "manufacturing defect ... 'exists only where an item is substandard when compared to other identical units off the assembly line."' Docket No. 56, 3 (quoting Wright v. Brooke Group, Ltd. (652 N.W.2d 159, 178-79); (Sec Nat'l Bank v. Abbott Labs, 2013).

To this assertion, the court responded:

Though Defendant does not draw this citation to its logical conclusion, the implication is clear: their product is intended to contain E. sakazakii, as well as other potentially harmful bacteria. First, if $75 \%$ of a product does not contain bacteria and $25 \%$ of a product does, elementary statistics dictates that the $75 \%$ without the bacteria constitutes the norm while the $25 \%$ with the bacteria constitutes a deviation therefrom. Second, a common defect, such as the persistent contamination of a food product with bacteria, if generally unknown and proven harmful, should increase a manufacturer's total liability, rather than eliminate it Sec Nat'l Bank v. Abbott Labs (2013).

Further, the court reasoned, since the defendant admitted that it has testing procedures to test for the presence of E. sakazakii and that it discards batches of the formula found to contain the bacteria, the presence of E. sakazakii is not part of the intended design, and its presence thus constitutes a deviation (Sec Nat'l Bank v. Abbott Labs, 2013).

Finally, the court asserted that the other court ignored the primary test for determining whether a product has deviated from its intended design: "a determination of whether the average, reasonable consumer, rather than government regulators or industry insiders, would expect a product to have the alleged defect" (Sec Nat'l Bank v. Abbott Labs, 2013) Restatement (Third) of Torts: Products Liability, \$2, comment g). The court explained,

While expressly rejecting consumer expectations as a test for whether a product has a design defect, the Restatement (Third) of Torts: Products Liability, notes the importance of consumer expectations in relation to manufacturing defects and, more specifically, food product defects; it provides: On occasion, it is difficult to determine whether a given food component is an inherent aspect of a product or constitutes an adulteration of the product. Whether, for example, a fish bone in commercially distributed fish chowder constitutes a manufacturing defect within the meaning of $\$ 2(a)$ is best determined by focusing on reasonable consumer expectations (Sec Nat'l Bank v. Abbott Labs, 2013); Restatement (Third) of Torts: Products Liability, \$2, Comments $\mathrm{g}$ and $\mathrm{h}$ ).

The plaintiff had alleged that neither the mother of the infant nor the ordinary consumer would reasonably expect the formula to contain E. sakazakii, and the court agreed. Despite that fact that the defendant had made no secret that the formula was not sterilized, "the average consumer would not, from that, infer that its baby formula contains life-threatening bacteria” (Sec Nat'l Bank v. Abbott Labs, 2013). As such, the court found that there were sufficient facts to establish a "defect" claim (Sec Nat'l Bank v. Abbott Labs, 2013).

The nature of the defect was central to the court's evaluation of a strict liability claim against the manufacturer, distributor and retailer of a candy product in Gentry v. The Hershey Company Liberty Distribution and Petco Animal Supplies Inc (2010). The facts, as disturbing as they are, were summarized by the court as follows:

On November 28, 2007, Plaintiff pulled a York Peppermint Pattie out of the candy stand at the Cookeville Petco store. At the time, she did not notice anything unusual about the product or its packaging and she proceeded to walk around the store. Plaintiff first noticed a problem with the York Peppermint Pattie after opening the package and biting into the candy. When she bit into the pattie, she noticed something "crunchy" in her mouth which was not the expected texture of a York Peppermint Pattie. When Plaintiff looked at the pattie, she observed at least one wormlike creature and black dots which she assumed to be feces.

Upon discovering the infestation, Plaintiff showed the candy to the store manager on duty. Plaintiff then visited her doctor, complaining of nausea and vomiting, and was treated for food poisoning. Plaintiff claims that discovering the larvae in the candy was traumatic and she has undergone a steady and intensive regimen of psychological counseling, which continues to date. Petco employees routinely check expiration dates of the candies for sale to ensure that they have not expired, and are supposed to see if any of the candy has torn or open packaging. The York Peppermint Pattie at issue in this case did not have an expired expiration date, and it is unclear whether there were any tears or holes in the packaging before Plaintiff opened the wrapping.

After the subject incident, the General Manager at Petco's Cookeville store, Kelly Darty ("Ms. Darty"), was called at home. Upon her arrival at work the following morning, Ms. Darty opened approximately ten remaining York Peppermint Pattie packages in the display and observed larvae or webbing inside approximately four of those packages. She then called Liberty Distribution to complain about the infestation and was allegedly told to discard the product and a replacement order would be shipped to the store.....The infestation in this case has been described as that of an Indian Meal Moth or an Almond Moth. Both types of moths are considered infesting moths in grains, including dog food, bird seeds, and other types of pet foods (Gentry v. The Hershey Company Liberty Distribution and Petco Animal Supplies Inc, 2010). 
The manufacturer and distributor's summary judgment was granted because the nature of the defect did not exist while in the care, custody, and control of these defendants. The court explained: "There is no evidence that the York Peppermint Pattie at issue in this case was in a defective or unreasonably dangerous condition when it was in the hands of either Hershey or Liberty Distribution. Quite the contrary, all experts in this case agree that any infestation of the York Peppermint Pattie occurred while the product was in the exclusive possession and control of Petco" (Gentry v. The Hershey Company Liberty Distribution and Petco Animal Supplies Inc, 2010). As to Petco, the plaintiff's strict liability claim failed since the applicable Tennessee Product Liability Act of 1978 permitted a strict liability action against a seller only when the seller was also the manufacturer, or when the manufacturer cannot be located and served, or when the manufacturer has been declared judicially insolvent. However, the plaintiff's other causes of action were, in part, actionable against Petco and the case proceed forward against the pet store giant.

\section{b. Failure to Warn}

A product can be defective if it lacks a warning so that the consumer is aware of a danger in the product (Keeton et al., 1984; Clarkson et al., 2012; Cavico and Mujtaba, 2014; Cheeseman, 2016). However, there is no legal obligation to warn of dangers which a reasonable and rational consumer should be aware of, for example, that alcohol even in a caffeinated beverage product is dangerous if over-consumed (Cook v. MillerCoors LLC, 2011). A failure to warn case illustration is the California Supreme Court decision in Livingston v. Marie Callender's Inc (1999) where the court ruled that a seller of food is potentially liable for the failure to warn of an ingredient in the food to which a substantial number of the population are allergic, for example, MSG. Of course, the famous ("infamous" perhaps) failure to warn case (legal "saga" perhaps) is not an adulterated or contaminated food or beverage case. Rather, it was the McDonald's failure to warn of very hot coffee case (actually very, very hot coffee); and there was at one point a decision in favor of the injured plaintiff who was granted by the jury a $\$ 200,000$ compensatory damages award and a $\$ 2.7$ million jury punitive award; but the decision was appealed by both sides resulting in a confidential financial settlement (Segal, 2006).

In Sec Nat'l Bank v. Abbott Labs (2013) the plaintiff sued Abbott Laboratories, the manufacturer of powdered infant formula, arguing that the formula was the source of the bacteria that caused bacterial meningitis which led to the brain damage of a baby. Among other claims, the plaintiff asserted a claim for negligent failure to warn. Abbott sought summary judgment on this claim, arguing that regardless of the adequacy of Abbott's warning, the warning did not proximately cause the baby's illness because the baby's mother's decision to feed the baby the formula was entirely independent of Abbott's warning. Specifically, Abbott pointed out that the mother did not read the label warnings nor rely upon them when making the decision to use the formula. As such, Abbot argued, the warning language did not enter the mother's decision-making process when deciding to feed the formula to the baby (Sec Nat'l Bank v. Abbott Labs, 2013).

Interesting, the court explained that pursuant to a 2002 Iowa Supreme Court case, there was no longer a distinction under Iowa law between strict liability and negligence in the context of failure to warn claims. As such, the court chose to characterize the negligence claim not as negligence, but rather, as a "warning defect" claim (Sec Nat'l Bank v. Abbott Labs, 2013). As with negligence, the court explained that the causation element of a warning defect claim has two components: cause in fact and legal causation. The court further dictated that although Abbott made its argument for summary judgment in terms of lack of evidence of proximate cause, the nature of the challenge actually was based on factual causation. This was the case because the argument was that the mother did not read the label warnings nor rely upon them when making the decision to use the formula (Sec Nat'l Bank v. Abbott Labs, 2013).

The court rejected Abbot's claim that it was entitled to summary judgment; specifically, the court stated that the "argument fails because it misconstrues the nature of "factual causation" in a warning defect case. The question is whether the product was defective because it provided inadequate warnings and whether the omission of reasonable instructions caused the harm" (Sec Nat'l Bank v. Abbott Labs, 2013). Furthermore, the court stated that, in the context of a failure to warn claim, factual "cause can be established by showing a warning would have altered the plaintiff's conduct so as to avoid injury."' Mercer v. Pittway Corp., 616 N.W.2d 602, 624 (quoting Lovick v. Wil-Rich, 588 N.W.2d 688, 700). Indeed, this rule is entirely consistent with Restatement (Third): Products Liability $\$ 2(\mathrm{c})$, which frames the definition of a warning defect, in part, in terms of whether "the foreseeable risks of harm posed by the product could have been reduced or avoided by the provision of reasonable instructions or warnings," and Restatement (Third): Products Liability $\$ 1$, which frames the causation element in terms of whether the omission of reasonable instructions or warnings caused the harm (Sec Nat'l Bank v. Abbott Labs, 2013).

The court explained that Abbott's contention that the mother did not read the label (or did not consider the warnings on the label) does not destroy the warning defect claim. The court reasoned that the plaintiff had created a genuine issue of material fact as to causation when the mother stated that she would not have fed the baby the formula if the label had stated it was unsuitable for an infant under 28 days, that it may contain harmful bacteria, or that liquid formula was safer (Sec Nat'l Bank v. Abbott Labs, 2013).

Failure to warn theories sounding in strict liability or negligence do not always produce the same outcomes relative to food manufacturers and supermarket retailer defendants for the very same deleterious food item. In Porrazzo v. Bubble Bee Foods LLC \& The Stop and Shop Supermarket Company LLC (2011) as to the plaintiff's "failure to warn" strict liability claim against both Bubble Bee Foods, the manufacturer of the canned tuna containing levels of mercury, and the supermarket seller of the same tuna cans survived the defendant's motion to dismiss. The judge explained that the:

Plaintiff here has adequately set forth a strict liability failure to warn claim. As noted above, he has established both injury and proximate cause, and has sufficiently alleged that the dangers of mercury poisoning from consumption of canned tuna fish are not open and obvious. Further, there is no suggestion at this stage that this particular plaintiff was, in fact, aware either that canned tuna fish contained methylmercury or that there were risks inherent in the consumption of fish which contained high 
concentrations of this substance. See Colon ex rel. Molina, 199 F. Supp. 2 d at 85 ([HN36] "A failure-to-warn inquiry focuses on three factors: obviousness of risk from actual use of product, knowledge of the particular user, and proximate cause."). Finally, the fact that methylmercury in tuna may be "naturally occurring" does not necessarily mean Defendants cannot be strictly liable for failing to warn customers of same (Porrazzo v. Bubble Bee Foods LLC \& The Stop and Shop Supermarket Company LLC, 2011 ).

However, the negligence claim for "failure to warn" of the same potentially dangerous condition of the same canned tuna could be had against Bubble Bee Foods as a manufacture but not the supermarket seller of the tuna. The court explained it this way:

Plaintiff has also adequately alleged a negligent failure to warn claim against Bumble Bee, because "[r] egardless of the descriptive terminology used to denominate the cause of action (viz, 'strict liability' or 'negligence'), where the theory of liability is failure to warn, negligence and strict liability are equivalent." [citing case precedent]. Defendants' motion to dismiss Plaintiff's claim against Bumble Bee for negligent failure to warn is thus likewise denied. Defendants are correct, however, that Plaintiff's negligent failure to warn claim cannot be sustained against Stop \& Shop. Under a negligence theory of liability, a "retailer ... . can be held liable . . . for the sale of a defective product or for failure to warn only if it fails to detect a dangerous condition that it could have discovered during the course of a normal inspection while the product was in its possession." [citing case precedent] Consequently, Defendants' motion to dismiss Plaintiff's claim (within Count II) for negligent failure to warn against Stop \& Shop is granted (Porrazzo v. Bubble Bee Foods LLC \& The Stop and Shop Supermarket Company LLC, 2011).

\section{c. Design Defects}

A product is defective if it is defectively designed. Note that the product is not necessarily flawed; it is doing what it is supposed to do; and the warnings are adequate. Nonetheless, under strict liability law the issue is whether the design of the product is defective. In order to determine if a product is defectively designed the courts apply three tests: 1) the state-of-the-art, 2) practical feasibility, and 3) economic feasibility. Regarding the first test, the courts would instruct a jury to go back in time to when the product was made (and not at the time of the lawsuit) and ask, based on the level of science, technology, and engineering then in existence, whether the product could be made safer. As to the second test the issue is whether the product could be made safer and still function as a product of that type. For example, a knife could be made very safe but it would be useless as it would not cut! Lastly, could the product be made safer from an economic feasibility perspective? That is, could the product be made more safe and still be affordable, perhaps as an "economy product." Lipp and Hafer (2014) provide an example of a possible design defect from the Restatement (Third) of Torts: Products Liability, to wit: when the recipe for potato chips contains a dangerous chemical preservative for which there is an alternate preservative. The object of strict liability is to advance safety and not to bankrupt the manufacturer. Any one of the aforementioned types of defects will be sufficient to trigger strict liability (Keeton et al., 1984; Clarkson et al., 2012; Cavico and Mujtaba, 2014; Cheeseman, 2016). Food and beverages are certainly counted as products for strict liability analysis. As a result of consumer activism and also as a possible concern about products liability lawsuits, many companies, for example KFC and Dunkin' Donuts, have made their products healthier and safer by eliminating trans-fats (Caruso, 2006; Jewell, 2007).

Lawsuits that allege design defects against a food manufacturer appear to be the most difficult claims for plaintiffs to prove (Benton, 2012). This is because "A food product is defective in design only when there is a foreseeable risk of harm, which could have been avoided by using an alternative design. In the case of foods (excluding meat and poultry), there is only one way to grow them; i.e., farming. Further, because of section 103 of the Food Safety Modernization Act (FSMA), if there is an alternative design that is less dangerous to consumers, it will likely have already been in place and approved by the FDA" (Benton, 2012).

\section{Defenses}

The main defenses to strict liability are the aforementioned assumption of the risk doctrine, disregarding instructions, and the misuse and/or abuse of a product (Clarkson et al., 2012; Cavico and Mujtaba, 2014; Cheeseman, 2016). However, it is worth noting that if the grocery store was not owned or operated by a defendant when the alleged defective food product was sold to the customer, this would defeat a claimant's case sounding in strict liability. This was explained in Campbell v. Supervalu Inc (2008) where the alleged E. Coli tainted meat was sold by the prior owner of the grocery store, and thus the current owner could not be held liable. In granting the grocery store's summary judgment the court explained:

Under the rubric of strict liability, [the Campbells] must prove that: (1) the product was defective and unreasonably dangerous; (2) the defective condition existed at the time the product left [Supervalu's] control; and (3) the defective condition was the proximate cause of [Michael's] injuries." [citing case precedent]. Once again, Supervalu asserts that the ground beef was never in their "control" so as to impose liability. Because the Campbells have not shown on this record that Supervalu was either the seller of the ground beef, or that the ground beef was tainted, or for that matter that it caused Michael's injury, we believe that summary judgment must be granted (Campbell v. Supervalu Inc, 2008).

\section{Preemption by Statute}

Preemption is a legal doctrine that holds that when a federal law occupies a regulatory field by means of extensive and pervasive regulation Congress, in effect, has "spoken" on the matter, and thus the federal law supersedes any conflicting state law (Cavico and Mujtaba, 2014; Mortazavi, 2016). A relevant preemption case to the analysis, though not a direct precedent, is the 2009 Supreme Court decision in Wyeth v. Levine. In the case a plaintiff who had to have her arm amputated argued that the defendant manufacturer, Wyeth, argued that the company was negligent and strictly liable for the defective product for not providing a warning of the risk of injecting the drug directly into her arm. The jury found for the plaintiff; and the Vermont Supreme Court affirmed the decision. The company appealed to the U.S. Supreme Court, arguing that the FDA's drug labelling regulations 
and requirements pursuant to the Food, Drug, and Cosmetic Act preempted her state product liability claims (Wyeth v. Levine, 2009). The Supreme Court, however, refused to rule that the FDA regulatory scheme for labelling drugs preempted state law because of the lack of an express Congressional intent to preempt state law (Wyeth v. Levine, 2009). The Supreme Court explained: "If Congress thought state-law suits posed an obstacle to its objectives, it surely would have enacted an express preemption provision at some point during the FDCA's 70year history....its silence on the issue, coupled with its certain awareness of the prevalence of state tort litigation, is powerful evidence that Congress did not intend FDA oversight to be the exclusive means of ensuring drug safety and effectiveness" (Wyeth v. Levine, 2009). To compare, Mortazavi (2016) points to a 2013 federal district court case, Lateef $v$. Pharmavite, where the plaintiff's breach of warranty and other state claims based on the alleged mislabeling of vitamins as vegetarian were deemed to be preempted by the federal law, specifically the National Labeling and Education Act (NLEA), because NELA contained an express preemption clause to ensure the uniform labeling of food products.

Accordingly, Benton (2012) argues that one way to improve food safety would be to allow the Food Safety Modernization Act to preempt state regulations and state laws regarding food safety, which presumably would include state common law lawsuits for negligence and strict liability as well as state statutory warranty law pursuant to the Uniform Commercial Code. Such a preemption policy, Benton (2012) argues, "could promote economic interests by keeping food manufacturing costs low and thereby allowing consumers to continue purchasing affordable food products." There is a precedent on the federal level, Benton (2012) points to, and that is the preemption effect of state claims by the Food, Drug, and Cosmetic Act (FDCA). Benton (2012) explains that such preemption for food,

...would also bring the FSMA closer in line with the FDCA, which preempts state claims regarding medical devices where the state law adds or takes away from the FDCA. The policy behind limiting the liability of medical device manufacturers was to spur innovation, even though individuals are sometimes injured when using medical devices. Such a policy promotes medical advancement and economic interests (pp. 49-50).

There is another preemption precedent, moreover, though not quite as direct as the FDCA one, on the state level. This preemption situation deals with negligence and harassment claims brought by employees against their employers for harms and injuries caused by fellow employees. Many state courts have held that these common law and civil rights claims are preempted by state Workers' Compensation laws (Cavico et al., 2016).

Thus far, the legal analysis provided by the authors first explained and illustrated the basic principles underlying the three main legal theories - negligence, warranty, and strict liability - used by injured consumers to bring lawsuits against manufacturers, supermarkets, and grocers for contaminated and unwholesome food and beverage products. Then the authors presented and explicated recent case law decisions against the aforementioned entities based on the three legal theories. However, it needs to be pointed out the courts seem to use the terms "merchantable," "wholesomeness," and "fitness" interchangeably; and, moreover, as noted, a "reasonable consumer expectations" test arises in Section 402A the Restatement (Second) of Torts and thus finds its way into strict liability law as well as warranty law, all of which adds to the confusion in this area of food and beverage liability law (Getz, 1994). In the next section of the article the authors discuss the implications of this legal environment and the preceding legal analysis, first generally and then in the context of the three legal theories.

\section{Implications for Management}

\section{A. Generally}

Today, supermarkets and grocers as well as traditional restaurants are now competing for consumers who want freshly-prepared meals as opposed to conventional "home-cooking" or even standard restaurant meals. The result has been an increase in the amount of these "fresh" offerings as well as their complexity. These more complicated meals require more specialized cooking and serving practices. Consequently, supermarkets, grocers, and restaurants now have to deal with heightened food safety issues as the first two entities are now acting like mini-restaurants and the traditional restaurants are now doing much more take-out business and thus acting like grocers. The authors discuss the implications of their legal analysis for employers and managers in the frame of the three major legal theories adduced herein.

First and foremost, one must be aware that manufacturers, supermarkets, grocers, as well as restaurants, and other entities on the food chain are not guarantors or insurers. That is, the injured must be able to utilize and support from legal, evidentiary, and proof and persuasion grounds one of the three legal theories discussed herein or other legal avenues to obtain redress. For example, pursuant to negligence law "merely" ordinary care and prudence are required. And although there are beneficial legal doctrines, such as res ipsa loquitur and negligence per $s e$, and although strict liability is "strict," the consumer, regardless of the legal theory being employed, still must be able to demonstrate that his or her foodborne illness was caused by the unwholesome food or beverage. The mere fact of eating certain food or consuming a certain beverage and then getting ill is insufficient; rather, causation factual and proximate - is required.

\section{B. Pursuant to Negligence Law and Practice}

First to be discussed are the implications that arise from negligence law. Pursuant to negligence principles a seller or provider of food has a duty to act as a reasonably prudent person knowledgeable and skilled in the culinary arts and sciences of food selection, storage, preparation, and cooking, including the detection and removal of harmful substances from the food. Knowledge of government safety standards is essential since failure to comply with government standards is evidence of negligence. The Wall Street Journal (Haddon and Nassauer, 2016; Newman, 2016) provided two examples of cooking safety standards to illustrate the complexity of this area: first, chicken prepared for a chicken biryani dish on a hot buffet must be cooked at least 165 degrees for a minimum of 15 seconds, then "cooled" two hours to 70 degrees in order to prevent bacteria, like salmonella, for occurring; and second, rice prepared for a cold Mediterranean pilaf salad must be cooked to 135 degrees, then "cooled" for two hours to 70 degrees, and chilled for an additional four hours at 41 degrees in order to prevent spores from growing 
and thereby contaminating the food. Another example involves oysters, where temperature control is critical. In order to prevent the fast-growing Vibrio vulnificus bacteria from contaminating the oysters they must be cooled within two hours after being taken out of the water to bring their internal temperature down to 55 degrees (Kestin, 2016). Consequently, the failure of an entity on the food marketing chain to comply with industry, government, or its own standards of manufacture, storage, handling, preparation, and serving of food or beverages is evidence of negligence.

Causation, both factual and proximate, is a required element to a negligence claim (as well as warranty and strict liability). Yet demonstrating causation likely will be a challenge for the injured consumer, especially in foodborne illness claims. Cogan (2016) explains the problem, to wit: “...The victim cannot connect the foodborne illness with a particular source, he or she suspects a particular food source but no longer possesses the evidence (i.e., the food is gone and there are no leftovers), no lab tests were conducted to confirm the presence of foodborne pathogen, or the victim simply cannot remember what he or she ate." The source problem is particularly acute when it comes to foodborne illnesses caused by oysters as it is very difficult to tell where the oysters come from and thus who is accountable. As such, there are uncertainties as to where the oysters are harvested, including perhaps closed and prohibited areas; restaurants serve oysters purchased from multiple dealers; mislabeling and relabeling by dealers occurs despite FDA regulations, inspections, and fines; Gulf oysters are substituted for Northeast oysters because the former are cheaper; and "it's not uncommon for oysters to go through two or more dealers before being sold to a restaurant” (Kestin, 2016).

The doctrine of res ipsa loquitur was created to benefit injured plaintiffs who could not obtain direct evidence of a lack of due care to satisfy the breach of duty element of a negligence lawsuit. However, Benton (2012) emphasizes that the burden of proof for an injured plaintiff is a "heavy one" in a food situation under res ipsa loquitur. Benton (2012) lists several reasons, to wit: 1) Proving that the food became adulterated and contaminated while under the defendant's control is a difficult task “...since the food industry is large and complex, and a product can pass through the hands of many different people or companies before reaching the grocery stores or restaurants." 2 ) A person with preexisting illnesses, for example, a stomach disorder, would have to show by means of expert medical witness testimony that his or her particular illness resulted from the defendant's food or beverage product and not any other existing medical illness. 3) For a plaintiff who has eaten previous meals the burden will seem "overwhelming" because "...he must also prove that everything else he ate on the same day he consumed the manufacturer's product, or even the same week, did not cause his illness. Accepting the assumption that an average person eats at least three times a day over a seven-day period, there could be at least twenty meals, not counting the manufacturer's product, which the plaintiff faces the challenge of disqualifying as the cause of his illness." 4 ) Another variable which compounds the problem for the plaintiff is “... whether there is any possibility another agent might have caused the contamination before the product reached the plaintiff, or whether the plaintiff caused the illness through his own negligent preparation or even storage of a product." 5) Finally, the food system in the U.S. is "complex," meaning that "by the time a food product has reached the supermarket it has traveled countless miles and been handled by several players, from distributors to brokers. Any one of these players might have acted negligently and caused the plaintiff's illness, rather than the manufacturer." Cogan (2016) agrees:

Undoubtedly, our highly complex food chain contributes to the problem. Foodborne pathogens can infect food at any point in the production and distribution process. Contamination can occur at a farm, during transport, at a processing plant, in a restaurant, in a supermarket, or even in our own homes. Industrialized food production, long supply chains, and market pressures to reduce food production costs all increase the risk of contamination by foodborne pathogens. As food processing or shipping systems have continually grown larger and more efficient, foodborne illnesses have become a national problem (pp. 1504-1505).

Therefore, Benton (2012) concludes as follows: "Thus, while res ipsa loquitur may seem to be a viable tool for plaintiffs who would bring a claim against a food manufacturer whose product they suspect made them sick...courts apply a very stringent set of rules that make it difficult for plaintiffs to succeed.”

\section{Pursuant to Warranty Law and Practice}

The second series of implications are those derived from warranty law. The trend in the jurisdictions away from the traditional "foreign/natural" test to determine whether food/beverages are "fit for human consumption" under the UCC to the "reasonable expectations" test gives the injured consumer more leeway in bringing a lawsuit as well as affording a jury (perhaps sympathetic to the injured consumer) the power to answer the "reasonableness" of the consumer's expectations. A consumer would no longer be under some type of duty of care to break apart food, inspect it, seek out and hunt foreign objects, or cut, slice, or pick at food with a knife or fork that was meant to be eaten out of hand. Eller (1993) criticizes the foreign/natural test as being "arbitrary and capricious" and applauds jurisdictions that have adopted the "more principled approach" of "reasonable expectations." The key, therefore, is simply what the "reasonable" consumer would expect in his or her food or beverage.

Regarding the labeling component to "merchantability," Benton (2012) points out that food producers are not likely to place labels on fruits and vegetables concerning the possible presence of bacteria; but Benton (2012) also emphasizes that "consumers do not buy fruits and vegetables that can lead to kidney failure and death."

\section{Pursuant to Strict Liability Law and Practice}

The third part to the discussions of legal consequences deals with the tort of strict liability. Generally, a food strict liability claim would consist of the following elements: 1) the food is in some way "defective" and thus is unreasonably dangerous to the consumer; 2) the food is expected to and in fact does reach the consumer without any substantial change in its condition; 3) the food caused (factually and proximately) the consumer's illness or injury; 4) the defendant was the "seller" (i.e., on the food-chain); and 5) the consumer sustained damages (Lipp and Hafer, 2014). A product is defective if it is "flawed." As noted, the manufacturer must adhere to its own rules and standards. As such, as Benton (2012) points out: "Thus, there is an incentive for food manufacturers to remain in compliance with their own established standards. Such standards must be reported to the FDA and updated every three years under the FSMA anyway." 
Regarding the failure to warn component to strict liability in tort if there is a lack of a warning or an adequate warning (or labels, branding, or instructions) that indicated that the food or beverage product was unsafe or dangerous tort liability of the manufacturer (or any entity on the food marketing chain) could ensue. Lipp and Hafer (2014) in examining Colorado law, provide the example of a required warning when there is an unknown ingredient that can cause harm, for example, that the dye applied to the skin of oranges contains a well-known allergen. However, as emphasized, warnings are required only when it would be reasonable to do so; and thus there is no liability for failure to warn of widely known risks based on Colorado law, for example, that some consumers may be allergic to strawberries, or that the excessive consumption of alcoholic beverages can be injurious to one's health and safety (Lipp and Hafer, 2014). The Supreme Court of Illinois especially advises that warnings would be most appropriate in a jurisdiction that uses a "reasonable expectations" standard for liability, for example, by warning that pecan shells could be found in chocolate-covered pecan candy (Jackson v. Nestle-Beich Inc, 1992). Nevertheless, Benton (2012) foresees a major practical and legal problem with the utilization of this theory as a means of recovery for the injured consumer, to wit:

The plaintiff would have to prove that a reasonable person in the manufacturer's position would have provided a warning about the product. However, food manufacturers are not likely to place a product on the market they believe will cause a food-borne illness, and products such as fruits, vegetables, and nuts do not easily lend themselves to the ready discovery of whether they are adulterated in the same way that alcohol is known to be dangerous. In addition, food manufacturers are highly unlikely to put a warning label on such products because such a label would be off-putting to consumers. Consumers want to feel confident when they bit into an apple that it is completely safe. Consumers cannot do this with the thought of a warning label in the back of their mind that they might become sick later. If this were the case, they would likely not buy the product (pp. 46-47).

As to the design defect aspect to this tort, it appears that it is going to be challenging to demonstrate that food and beverages are defectively designed so that they are unreasonably dangerous to the consumer. Yet can food and beverages be made healthier? The answer is likely "yes"? But are food and beverages defectively designed products because they could be made more healthful? The answer is likely "no" due to the requirements for design defect liability under strict liability. In particular, defining what types of food and beverages are healthy or unhealthy or stating which types could be made more healthful is an exceedingly difficult task indeed (Campos, 2015). What are the alternative ingredients to food and beverages? Are they safer alternatives? Benton (2012) adds that "in the case of foods (excluding meat and poultry), there is only one way to grow them, i.e., farming." Moreover, Campos (2015) warns that "nutrition science is beset by contradiction, uncertainty, and complexity. Under the circumstances, the tendency of public health authorities to divide food into 'good' and 'bad' categories, and to prescribe homogeneous dietary patterns to heterogeneous populations, is an example of both intellectual hubris and overweening public policy."

\section{Recommendations for Management}

Contaminated food that makes the consumer ill can make the food manufacturer and the other entities on the food chain sick as well. Food businesses, their shareholders, employees, and other stakeholders know full well that the slightest outbreak of a foodborne illness can seriously damage the reputation of a food business and consequently result in severe financial harm. Accordingly, based on the discussion of the implications of the preceding legal analysis, the authors' own knowledge and experience, as well as legal and management commentary, the authors offer the following suggestions to employers and managers to avoid liability.

First, the authors would like to stress one very basic and very important recommendation - thoroughly Wash Your Hands with warm water for at least 15-20 seconds. Obviously, employees working with food must be told in strongly, clearly, and regularly to wash their hands while working with and handling food and beverage items. Certain food items also must be rinsed thoroughly, for example, lettuce. Another very basic recommendation is that when dealing with food to cover one's hair. In addition to improper hygiene by food handlers, managers must be aware of the main causes of foodborne diseases - improper storage, improper cooking and preparation, especially not heating or refrigerating food properly, cross-contamination, and otherwise inadequate handling of food and its ingredients (Cogan, 2016).

A critical feature in avoiding legal liability concerns the proper storage of food. When food is received from the vendor, it first needs to be immediately inspected by the person in charge of deliveries. The food items must be examined in a scrupulous manner to ensure that acceptable standards have been adhered to before being removed from the shipping vessel. The food then needs to be washed and stored into clean, imperforated, plastic containers, which are sanitized, and then labeled according to the specific items, and dated. All storage items, regardless if they are dry goods (such as flour, salt, sugar), or perishable goods, (such as milk, eggs, or cheese) should be organized using the FIFO system (first-in, first-out) and stored with the older items in front of newer ones. All consumable items, regardless if they are still good, need to be discarded 12 months after delivery.

Foods, which are time and temperature controlled for safety, are referred to as "TCS." These items include meat, fish, cooked foods, vegetables, fruits, dairy products, infused oils, and other items not considered dry storage, meaning they cannot be stored at ambient temperature (room-temperature). TCS items should always be stored out of the food danger zone of $41^{\circ} \mathrm{F}\left(5^{\circ} \mathrm{C}\right)-140^{\circ} \mathrm{F}\left(60^{\circ} \mathrm{C}\right)$. Items received should never be over $41^{\circ} \mathrm{F}\left(5^{\circ} \mathrm{C}\right)$ (ServSafe, 2016). The person receiving TCS items should have a calibrated instant-read thermometer; and he or she should check all items for quality, quantity, and temperature. All TCS foods should be stored in a refrigerator or freezer in a certain order to prevent cross-contamination. Meat/fish, dairy, and vegetables should all be stored separately. When storing a "protein" meat or fish, the refrigerator should be organized in this order, to wit: 1) ready to eat foods; 2) seafood; 3) whole cuts of beef, lamb, veal, pork; 4) ground meats and ground fish; and 5) whole and ground poultry (ServSafe, 2016). The refrigeration order for the vegetables and fruits is less strict, but order also should have a descending order, to wit: 1) the ready to eat foods; 2) already cut foods for preparation; 3 ) vegetables/fruits which do not have an allergy association; and 4) vegetables/fruits which do have a possible allergy association. 
Today, modern restaurants and supermarkets have many foods which are storage vacuum-packed. Some even cook their items "sous-vide" (French for "under vacuum"). When vacuum packing foods, the chef needs to make certain that the food is very cold $38^{\circ} \mathrm{F}\left(3.3^{\circ} \mathrm{C}\right)$ or under. The food item can be seared, but it must be chilled immediately and thoroughly. The chilled food needs to be sealed and and either cooked immediately or stored at $38^{\circ} \mathrm{F}\left(3.3^{\circ} \mathrm{C}\right)$ or below. When cooking sous-vide, the food must be cooked to the desired "doneness," then removed from the bag and served. Conversely, the food can be cooked, left in the bag, and chilled in an ice-bath, (at a minimum of $50 \%$ ice, but the more ice the better), to $34^{\circ} \mathrm{F}\left(1^{\circ} \mathrm{C}\right)$, then refrigerated or placed in a freezer $($ Keller, 2008). The food must be stored in the refrigerator (chilled first if it has been cooked) at or below about $38^{\circ} \mathrm{F}\left(3.3^{\circ} \mathrm{C}\right.$ ) or frozen. Food must be in the refrigerator before using any vacuum-packed items. Food vacuum-packed for storage, will last considerably longer in the refrigerator than wrapped in plastic; and the food also holds up better in the freezer. The main reason is because of the removal of oxygen from the food's environment. Lack of oxygen greatly reduces the activity of many bacteria that cause spoilage. In the freezer, the vacuum-sealing keeps the food from losing moisture to the air, preventing freezer-burn (Keller, 2008). Cooking and then storing food "sous vide" has the additional benefit of detracting airborne bacteria from a cutting board or a cook's hands, and these actions will further delay spoilage. Storing food this way helps to maintain the shape of the food and it is also neater, cleaner, and more hygienic (Keller, 2008).

Regardless of the method of storing TCS food items, or the cooking method used, the maximum time-period for food storage in the refrigerator is 7 days. "HACCP" or Hazard Analysis Critical Control Points, which all USDA and FDA inspected facilities must use, have additional rules, which should be adopted by all restaurants, supermarkets, and manufacturers. Two examples are: 1) all cold items should be $41^{\circ} \mathrm{F}\left(5^{\circ} \mathrm{C}\right)$ or lower; 2$)$ the temperature of a cooling cooked item should reach a minimum temperature of $70^{\circ} \mathrm{F}\left(21.1^{\circ} \mathrm{C}\right)$ in the first two hours with four hours to degrees of the temperature from $70^{\circ} \mathrm{F}\left(21.1^{\circ} \mathrm{C}\right)$ to $41^{\circ} \mathrm{F}\left(5^{\circ} \mathrm{C}\right)$ or under (ServSafe, 2016$)$.

Another problem food area that can result in legal liability is cross-contamination. Cross-contamination can occur in the storage of food and also within the service of the kitchen and the restaurant staff during prepping or during service. Cross-contamination can occur with an employee's hands, customer interaction, or contact with infected surface areas. Although cross-contamination is mainly associated with items such as raw chicken, with a cooked product, often overlooked, is cross-contamination associated with food allergies. To reduce the chances of cross-contamination, recognition must be given to items which have a high chance of salmonella, such as chicken and turkey products; items that will not be cooked; and items that have allergy associations. Employees who are handling these items need to use plastic gloves, wash their hands immediately after disposing the gloves, and clean and disinfect the work-stations (ServSafe, 2016).

Professional kitchens should have hard-plastic cutting boards, which are dishwasher safe, and the employees should use different color cutting-boards to identify exactly what items are to be used on the associated colorcutting board. For example, a system which establishes the fixed-rule that raw poultry will only be cut on an orange cutting board can alleviate many cross contamination problems. Having a system like this in place will help trained employees have immediate recognition if someone is not using the right-colored cutting board. A reason to have hard-plastic dishwasher-safe cutting boards as opposed to wood cutting-boards is that the wood board has no real way of being totally disinfected. When put into a dishwasher the wood board will likely warp and bacteria can develop in the nicks in the wood leading to a bacteria-infused cutting-board.

In the food production-world there are eight foods categories that account for $90 \%$ of all allergies, and that by law must be disclosed on the food items nutritional fact panel. The eight foods categories are anything that contains milk, eggs, fish, crustacean shellfish, tree nuts, peanuts, wheat, and soybeans. The name of the food source of a major food allergen must appear in parentheses following the name of the ingredient; for example: "lecithin (soy)," "flour (wheat)," "whey (milk)." Or they must appear immediately after or next to the "list of ingredients" in a "contains" statement, for example: "contains wheat, milk, soy" (ServSafe, 2016). Also, it is recommended that food allergy sufferers immediately inform their restaurant or server or supermarket sales clerk of their allergy to alleviate possible food contamination. The server or sales clerk will then inform the chef and staff of the allergy, who will then need to use separate tools, cutting boards, and other kitchen items, so every step is taken to avoid possible cross contamination.

Another possible way that cross-contamination can occur is if the customer happens to touch something unintentionally either with his or her hands, utensil, or bodily fluids. Cross-contamination can easily happen in a buffet-style restaurant or supermarket salad bar because people can touch the food. Although many of these buffetstyle food services have sneeze-guards to prevent bodily fluids and also supply special utensils, such as a pair of tongs, to prevent people from touching the item; yet, unfortunately, many people use other utensils to pick up an item. Accordingly, it is recommended that utensils be replaced often, signs posted listing the specific ingredients in the item, and designate an employee to watch out for possible cross-contamination problems.

It is also very important for manufactures, supermarkets, grocers, and restaurants to avoid common illnesses. Freezing is a relatively modern development in food storage. Freezing will preserve meat indefinitely; however, it can diminish food quality by not only physical damage but also with rancidity. Freezing an item will physically make the water in the cell membranes form ice crystals and thereby be physically punctured. When the items are thawed, the punctured cell membranes leak salts, vitamins, proteins and other nutrients that will make the food not taste as good as it once was McGee (2004). A cooked item normally holds up to freezing because the item has been already transformed during the cooking process and consequently much of the water has already been lost. Freezing also causes a chemical change in animal-based food products. Ice crystals remove the muscle fluids and water, thereby allowing for increased concentration of salts and trace metals that promotes oxidation and rancidity (McGee, 2004). Most meat products should only be frozen for no longer than one year; poultry six months; fish, shellfish, and ground meats for less than six months. When thawing a product, it should be wrapped in an ice-bath or left in the refrigerator until the item is completely thawed. Hot water should never be used in thawing because it causes the rapid growth of dangerous bacteria (McGee, 2004).

Red meat has a unique problem because of specific likes by the customer. The main risks involving food poison of uncooked red meat are the bacteria of Listeriosis and Escherichia coli. For instance, rare meat needs a certain 
temperature of $125^{\circ} \mathrm{F}\left(51.6^{\circ} \mathrm{C}\right)$ or less; medium rare $135^{\circ} \mathrm{F}\left(57.2^{\circ} \mathrm{C}\right)$; medium $140^{\circ} \mathrm{F}\left(60^{\circ} \mathrm{C}\right)$; and well done above $150^{\circ} \mathrm{F}\left(65.5^{\circ} \mathrm{C}\right)$; but at temperatures above $160^{\circ} \mathrm{F}\left(71.1^{\circ} \mathrm{C}\right)$, the meat would lose most of its moisture and become too dry to enjoy eating. Bacteria are located on the meat's surface and not inside the meat. As long as the surface is thoroughly cooked, the bacteria will be killed and the meat can be enjoyed at the desired temperature (McGee, 2004).

Salt is the most important ingredient in the kitchen. It is used in every cuisine either directly or indirectly. Salt will "make or break" a dish. Too little, and the food will taste bland; and too much and the food will be inedible. Salt is made up of two elements: sodium and chloride. Salt has provided economic stability to many early civilizations (for example, the city of Salzburg in Austria); and salt has provided a means for preserving food in order for civilization to survive to this day. What destroys food is not time, but tiny microbes and bacteria that causes food to spoil and rot. Salt preserves meat by depriving bacteria molds of water. Salt dissolves the sodium and chloride ions outside of the microbes and water the inside of their cellular walls. These salted microbes are either killed or actually dehydrated and thus drastically slow down the spoilage process (Ruhlman et al., 2005).

Salt, especially the nitrite $\mathrm{NO} 2$, suppresses the oxygen intolerant Clostridium Botulinum which causes the extremely deadly toxin botulism, which is toxin that cannot be cooked out of foods. Specifically, sausages are very prone to this deadly toxin. In fact, the word "botulism" comes from the Latin word "botulus," meaning "sausage." Nitrite inhibits important bacterial enzymes and interferes with its energy production making the sausage safe to eat. Nitrates and nitrites get a "bad press" because they can react with other food components to form possible cancer causing nitrosamine. However, in the United States, nitrates and nitrites in cured meats are limited to (0.02\%) 200 parts per million and are normally well below this limit for cancer concern (McGee, 2004).

Salmonella, which is one of the most common food poisoning "culprits" is found in many items, the most common being poultry, and also is found in eggs, which are the most common food items in any kitchen. Salmonella is very resilient to acidity and temperature. Salmonella is prevalent due to the industrial scale of poultry farming in the United States, where the over-crowding and close confinement of the animals help spread the bacteria (McGee, 2004). The only way to kill salmonella is to cook food to its proper temperature, normally known in the food world as the "magic number" of $165^{\circ} \mathrm{F}\left(73.8^{\circ} \mathrm{C}\right)$, in which bacteria will die in 15 seconds at that temperature.

The potential pathogens that can be considerably more dangerous when dealing with anaerobic environments are salmonella, clostridium botulinum, e.coli, and listeria. The longer bacteria exist in what is referred to as the "danger zone" of temperatures between $41^{\circ} \mathrm{F}\left(5^{\circ} \mathrm{C}\right)-140^{\circ} \mathrm{F}\left(60^{\circ} \mathrm{C}\right)$, the faster they multiply, and thus the more dangerous they become. Bacteria grow with exceptional speed at temperatures between about $100^{\circ} \mathrm{F}\left(37.7^{\circ} \mathrm{C}\right)-$ $120^{\circ} \mathrm{F}\left(48.8^{\circ} \mathrm{C}\right)$, doubling in number every $20-30$ minutes (Keller, 2008). Keeping food cold and chilling cooked food as quickly as possible can drastically reduce the bacteria's rate of growth. The maximum time food can safely remain in danger-zone temperatures (this includes cooking time if cooking below $140^{\circ} \mathrm{F}\left(60^{\circ} \mathrm{C}\right)$ ) is four hours. However, the sooner cooked food is out of the danger zone (meaning the faster it is chilled), the better, from both a safety and a spoilage standpoint. Any cooked or raw protein, which has been in the danger zone for four hours or longer, should be discarded immediately (Keller, 2008).

Mishandling food preparation and service is, as emphasized, a major area of concern. Many forms of food contamination, especially if caused by bacteria, can be prevented by the proper cooking of food, eating it promptly, or properly refrigerating the food. Thus, another strong suggestion would be for supermarkets, grocers, as well as restaurants to engage in training of employees as to the current food safety standards for storage, preparation, and serving. Online training is available, for example, with the International Dairy-Deli-Bakery Association which offers food safety courses for grocery store workers (Haddon and Nassauer, 2016; Newman, 2016).

The entities examined herein should attempt to identify any weaknesses or gaps that become apparent in the growing, manufacture, storage, selling, preparation, and serving of food and beverages. Testing and inspections, inhouse as well as through independent and certified third parties, must be conducted to ensure compliance with health and safety regulatory standards and to maintain the safety and quality of food and beverage products. Traceability emerges as another important safety factor; that is, an attempt must be made to know the origin of the food and its ingredients, as well as where the food was harvested or processed, so that if there is a problem the origin of the illness can be tracked, identified, and rectified. However, as noted herein, and again as emphasized: "Tracing the source of contamination responsible for a foodborne illness outbreak can be an onerous and complex process" (Bassett et al., 2009). Another suggestion would be to regularly close the kitchens and other cooking facilities for a "deep cleaning," as the cruise lines are now doing to avoid outbreaks of the norovirus. Tyson Foods, for example, has a Food Safety and Laboratory Services Network which conducts 280,000 tests per month at 18 labs across the country, a Food Safety and Quality Insurance Group to ensure regulatory compliance and to evaluate suppliers, and a Sentinel Site program of environmental monitoring that tracks the effective of its sanitation procedures, particularly to detect even low levels of E. Coli (Tyson Foods Food Safety and Quality Assurance Department, 2016). Chipolte Mexican Grill, which had to deal with an E. Coli outbreak in 2016, now has an extensive, and well publicized, food safety program called Food Safety Advancements (Jargon, 2016) which consists of supplier interventions, advanced technology, farmer support and training, enhanced food preparation procedures, food safety certification, and inspections. The goal of the program is to ensure that the food served is as "safe as possible" (Jargon, 2016). Nevertheless, the Wall Street Journal (Jargon, 2016) reported that Chipolte's profits plunged $95 \%$ in the third quarter of 2016. As per the prior illustrations, any entity on the food chain should have and follow explicit policies and procedures regarding to producing, receiving, storing, preparing, holding, and serving food in order to avoid adverse legal and financial consequences. This type of information will help to evaluate whether a particular seller's food is the source of a person's illness. Moreover, evidence of the existence of food safeguards and following those safeguards will help to negate any negligence accusations (Bassett et al., 2009).

If an incident does occur, the results of tests conducted by government entities - from the FDA to the local health department, of the food entity's facilities, personnel, equipment, and procedures will be important evidence. Of course, the food or beverage itself can be introduced into evidence, if possible. Evidence that other consumers or patrons did or did not become ill when served the same food or beverage is important too. Moreover, whenever 
possible create a contemporaneous report about the event as soon as possible thereafter, include documentation of statements made by the party or parties and any witnesses, photographs, and maintain and preserve any items involved in the incident, if feasible. Also, preserve any surveillance as well as any waivers or releases given and signed by the injured party (Corkran et al., 2016). Investigate the injured party's social media and networking sites and accounts which are publicly viewable for postings, messages, photographs, or other information that may be pertinent to the incident (Corkran et al., 2016). Be very careful to view only public sites so as to avoid any invasion of privacy claims. Remember that a person will not have a "reasonable" expectation of privacy in content on public sites, which is necessary to sustain an invasion of privacy lawsuit (Cavico and Mujtaba, 2016). Also, investigate if other consumers complained of foodborne illnesses at the time of the initial consumer complaint since usually for a foodborne illness numerous people will become ill; and thus if no other complaints are ascertained, then one must consider other possible causes for the illness besides food contamination or adulteration (Bassett et al., 2009). Similarly, if the consumer alleges a foodborne illness after eating a particular type of food or a particular meal determine who else ate the food or meal with the stricken consumer. So, if other people ate the same food or consumed the same meal and only the one stricken consumer became ill and the others did not the question is raised as to whether the food is the cause of the stricken consumer's illness (Bassett et al., 2009). Of course, if there is leftover food or containers for food that is possibly contaminated they must be properly stored to determine if they are truly contaminated to determine potential liability but also to try to determine the cause of the contamination so that other entities in the food chain as well as consumers can be warned and proactive measures can be taken (Bassett et al., 2009).

Another suggestion would be to put clear, simple, and prominent "warning" information on food and beverage products wherever feasible, for example, nutrition information, calorie count, and the dangers in misusing an item. Recall the failure to warn element of strict liability and the McDonald's hot coffee case and the "moral of the story" therein: It is cheaper to warn than to be sued for selling a defective product.

Since pursuant to strict liability law a manufacturer or any entity on the food-chain is strictly liable for "defective" food or beverage products, regardless if the manufacturers or others exercised due care, the authors would advise these parties to do the following: first to be cognizant of safety developments to keep up with the state-of-the-art; second, to exercise even greater care; third, to obtain products liability insurance in the form of food safety insurance as well as premises liability insurance, if warranted; and lastly, perhaps, to increase the price of the products to reflect the heightened safety standards and modifications and typically expensive insurance premiums.

\section{Summary}

Consumers have a legal and ethical right to know and to expect that the food and beverages sold by manufacturers, supermarkets, grocers, as well as restaurants, are in safe, wholesome, and unadulterated condition as well as properly branded and labelled. The aforementioned entities on the food chain are in a considerably more advantaged position compared to the consumer due to their knowledge and expertise and their role in making, storing, selling, preparing, and serving food. Thus these entities are under legal as well as ethical duties to take special care to try to ensure that the consumer is not harmed by adulterated and contaminated food products.

This article has sought to examine three major legal theories of liability - negligence, warranty, and strict liability - in the context of adulterated and contaminated food and beverages sold or provided by manufacturers, supermarkets, and grocers, as well as restaurants. The authors provided a basic explanation of the principles and elements underpinning these legal theories; and then illustrated their application by reference to and discussion of case law and legal and management commentary. Based on the legal analysis the authors then discussed the legal implications in these areas for the food entities examined herein. Finally, the authors provided recommendations to employers and managers on how to avoid liability under negligence, warranty, and strict liability law for adulterated and contaminated food and beverages. The authors trust that their legal and practical analysis and discussion herein will help employers and managers to fulfill their legal and ethical responsibilities to the consumer and thus to provide high-quality and safe food and beverages to the consumer.

\section{References}

Bassett, M.H., H.L. DeVault and B.A. Green, 2009. Meeting the challenges of foodborne Illness liability claims. Retrieved from http://www.foodsafetymagazine.com/mazzin-archive1/aprilmay-2009. [Accessed September 22, 2016].

Benton, D., 2012. The impact of mandatory recalls on negligence and product liability under the food safety and modernization act. San Joaquin Agricultural Law Review, 22: 27-50.

Bird v. Celebrity Cruise Lines, 2005. 428 F. Supp.2d 1275 (District Court for the Southern District of Florida 2005).

Brown v. General Foods Corp, 1978. 573 P.2d 930 (Arizona Court of Appeals 1978).

Burnett v. Essex Insurance Company, 2000. 773 So.2d 786 (Louisiana Court of Appeals 2000).

Campbell v. Supervalu Inc, 2008. 565 F. Supp. 2d 969 (Northern District of Indiana 2008).

Campos, P.F., 2015. Keeping it fresh?: Exploring the relationship between food laws and their impact on public health and safety: Essay: Food policy and cognitive bias. Wake Forest Journal of Law \& Policy, 5: 187-192.

Caruso, D.B., 2006. KFC's recipe soon to be trans-fat free. Sun Sentinel: 3D.

Cavico, F.J. and B.G. Mujtaba, 2014. Legal challenges for the global manager and entrepreneur. Dubuque, Iowa: Kendall Hunt Publishing Company.

Cavico, F.J. and B.G. Mujtaba, 2016. The intentional tort of invasion of privacy in the private employment sector: Legal analysis and recommendations for managers. International Journal of Business and Law Research, 4(3): 37-57.

Cavico, F.J., B.G. Mujtaba, M. Samuel and S. Muffler, 2016. The tort of negligence in employment hiring, supervision and retention. American Journal of Business and Society, 1(4): 205-222.

Chartis Specialty Ins. Co. v. Vaughan Foods Inc, 2017. U.S. Dist. LEXIS 13712 (District Court for the Eastern District of Missouri 2017).

Cheeseman, H., 2016. Business law. 9th Edn., Boston, Massachusetts: Pearson Education, Inc.

Clarkson, K.W., R.L. Miller and F.B. Cross, 2012. Business law: Text and cases. 12th Edn., United States: South-Western, Cengage Learning.

Cogan, J.J.A., 2016. The uneasy case for food safety liability insurance. Brooklyn Law Review, 81: 1495-1552.

Cohen v. Fairbank Reconstruction Corporation d/b/a Fairbank Farms, 2012.950 N.Y.S.2d 721 (N.Y. Sup. Ct. Albany Co. 2012$).$

Cook v. MillerCoors LLC, 2011. 829 F. Supp.2d 1208 (District Court of Appeals for the Middle District of Florida 2011). 
Corkran, C.T., J.M. Sette and J. Canton, 2016. Shop till you drop: Premises liability in retail and hospitality settings. Conroy-Simberg 28th Annual Claims Management Seminar. pp: 137-156.

Coulterv v. American Bakeries Company, 1988. 530 So.2d 1009 (Florida Court of Appeals 1988).

Cousineau, M., 2010. State food liability case law and statutes. [Accessed September 22, 2016].

Coward v. Borden Foods, 1976. 229 S.E.2d 262 (Puerto Rico Appeals 1976).

Deveraux v. McGarry's Inc, 1970. 266 A.2d 908 (Supreme Court of Rhode Island 1970).

Eller, B., 1993. Tort law - products liability - implied warranties - foods - Goodman v. Wenco Foods, Inc. North Carolina Law Review, 71 : $2163-2169$.

Encyclopedia of Medical Concepts, 2016. Food contamination. $\lceil$ Accessed 22, 2016 $\rceil$.

Ford v. Miller Meat Company, 1994. 28 Cal. App.4th 1196 (California Court of Appeals 1994).

Gant v. Lucy Ho's Bamboo Garden, 1984. 460 So.2d 499 (Florida Court of Appeals 1984).

Gentry v. The Hershey Company Liberty Distribution and Petco Animal Supplies Inc, 2010. 687 F. Supp. 2 d 711 (District Court for the Middle District of Tennessee 2010)

Getz, D., 1994. Products liability - illinois redefinest he standards of merchantability for food products: Reasonable expectations. Southern Illinois Law Journal, 18: 637-652

Goodman v. Wenco Foods Inc, 1992. 423 S.E.2d 444 (Supreme Court of North Carolina 1992).

Grinberg, E., 2009. FDA says residue is frog or toad; how did it get in pepsi can? CNN.com. [Accessed November 5, 2009].

Haddon, H. and S. Nassauer, 2016. Grocers forge ahead online. The Wall Street Journal: B6.

Haddon, H. and S. Nassauer, 2016. Grocers forge ahead online. Wall Street Journal: B6.

Hagan v. Coca-Cola Bottling Co, 2001. 804 So.2d 1234 (Supreme Court of Florida 2001).

Hensley-Maclean v. Safeway Inc, 2014. U.S. Dist. LEXIS 48591 (District Court for the Northern District of California, San Francisco Division 2014).

Hollinger v. Shoppers Paradise of New Jersey Inc, 1975. 340 A.2d 687 (Supreme Court of New Jersey 1975).

Hutchen v. Wal-Mart Stores East I LP. \& Juden, 2008. 555 F. Supp. 2d 1013 (District Court for the Eastern Dist. of Missouri 2008).

Jackson v. Nestle-Beich Inc, 1992. 589 N.E.2d 547 (Supreme Court of Illinois).

Jackson v. Winn Dixie Stores Inc, 1983. 439 So.2d 1147 (Louisiana Court of Appeals 1983).

Jargon, J., 2016. Chipotle profit plunges 95\%. Wall Street Journal: B6.

Jewell, M., 2007. Doughnut to be healthier. Miami Herald: 4A.

Keeton, W.P., D.B. Dobbs, R.E. Keeton and D.G. Owen, 1984. Prosser and keeton on torts (hornbook series). 5th Edn., St. Paul, Minnesota: West Publishing Company.

Kell, J., 2016. Bring home-cooking to your kitchen. Fortune: 44-45.

Keller, T., 2008. Under pressure: Cooking sous vide. New York: Artisan.

Kestin, S., 2016. Diners blindly trust those who skirt the rules. Sun-Sentinel: A, 8-9A.

Koperwas v. Publix Supermarkets Inc, 1988. 534 So.2d 872 (Court of Appeals of Florida 1988)

L.W. v. Tyson Foods Inc. \& Wal-Mart Stores East L.P, 2011. 2011 U.S. Dist. LEXIS 88338 (U.S. Southern of Miss. 2011)

Lipp, J. and E. Hafer, 2014. What's in the package: Food, beverage, and dietary supplement law and litigation. Colorado Lawyer, 43: 77-87.

Livingston v. Marie Callender's Inc, 1999. 85 Cal. Rptr.2d 528 (California Supreme Court 1999).

Marks, A.B., 2013. Check please: Using legal liability to inform food safety regulation. Houston Law Review, $50: 723$.

McCarley v. West Quality Food Service, 1998. 960 S.W.2d 585(Supreme Court of Tennessee 1998).

McGee, H., 2004. On food and cooking: The science and lore of the kitchen. New York: Scribner.

Miller v. Atlantic Bottling Corp, 1972. 191 S.E.2d 518 (Puerto Rico Appeals Court 1972).

Mix v. Ingersoll Candy Co, 1936. 6 Cal. 2d 674 (California Supreme Court 1936).

Mortazavi, M., 2016. Tainted: Food, identity, and the search for dignitary remedies. Brooklyn Law Review, 81: 1463-1492.

Newman, J., 2016. Safety issues stalk grocers' prepared meals. The Wall Street Journal: B1, B2.

Porrazzo v. Bubble Bee Foods LLC \& The Stop and Shop Supermarket Company LLC, 2011. 822 F. Supp. 2 d 406 (District Court for the Southern District of New York 2011).

Restatement (Second) of Torts, 1979. American Law Institute 1979.

Restatement (Third) of Torts: Products Liability, 1997. American Law Institute 1997.

Rouse v. George A. Hormel \&Co, 1976. 339 So.2d 1320 (Louisiana Court of Appeals 1976).

Ruhlman, M., B. Polcyn and Y. Solovyev, 2005. Charcuterie: The craft of salting, smoking, and curing. New York: W.W. Norton.

Schafer v. JLC Food Systems Inc, 2005. 695 N.W.2d 570 (Minnesota Supreme Court 2005).

Sec Nat'l Bank v. Abbott Labs, 2013. 947 F. Supp. 2d 979 (District Court for the Northern District of Iowa 2013); sanctions allowed by Sec. Nat'l Bank of Sioux City v. Abbott Labs., 2014 U.S. Dist. LEXIS 102228 (District Court for the Northern District of Iowa 2014).

Segal, M.E., 2006. The truth behind McDonald's hot coffee suit. Miami Herald, Business Monday: 8.

ServSafe, 2016. ServSafe essentials: Updated with the 2016 FDA food code. Chicago, IL: National Restaurant Association Solutions.

Simmons v. Brookshire Grocery Company d/b/a Brookshire's Food and Pharmacy, 2016. 194 So. 3 d 653 (Louisiana Second Circuit Court of Appeals 2016).

Southern States Coop v. Doggett, 1982. 292 S.E.2d 331 (Virginia Supreme Court 1982).

Spahn, E.M., 2011. Note: Keep away from mouth: How the American system of food regulation is killing us. University of Miami Law Review, 65: 699 .

Thacker vs. Kroger Company \& ConAgra Inc, 2005. 155 Fed. Appx. 946, (Eighth Circuit Court of Appeals 2005).

Tyson Foods Food Safety and Quality Assurance Department, 2016. Safety First. Fortune: 56.

U.S. Legal - Legal Definitions, 2016. Adulterated food law \& legal definitions. [Accessed September 22, 2016]

Velazquez v. Abbott Labs, 2012. 901 F. Supp, 2d 279; 2012 U.S. Dist. LEXIS 156427 (District Court for the District of Puerto 2012).

Wachtel v. Rosol, 1970. 271 A.2d 84 (Supreme Court of Connecticut 1970).

Way v. Tampa Coca Cola Bottling Co, 1972. 260 So.2d 288 (Florida Court of Appeals 1972).

Wikipedia, 2016. Foodborne Illness. [Accessed September 22, 2016].

Wikipedia, 2016. Adulterated food. Retrieved from https://en.wikipedia.org/wiki/Adulterated_food. [Accessed September 22, 2016].

Wikipedia, 2016. Food contaminant. [Accessed September 22, 2016].

Wyeth v. Levine, 2009. 555 U.S. 555 (Supreme Court 2009).

\section{Author Biographies}

Frank J. Cavico is a Professor of Business Law and Ethics at the Huizenga College of Business and Entrepreneurship of Nova Southeastern University in Ft. Lauderdale, Florida. He has served as a faculty member at the school for 30 years. He teaches business law and business ethics classes primarily at the graduate level in the MBA program; and Professor Cavico also teaches in the MPA program where he teaches the required Administrative Law and Ethics course. He has been the recipient of the Professor of the Year and Faculty of the Year Awards at the Huizenga School; and he was a nominee for the Professor of the Year Award for the university. $\mathrm{He}$ is the author of several books and numerous law review and management journal articles. Professor Cavico holds an LL.M degree from the University of San Diego, a J.D. from St. Mary's University, a Master's degree in Political Science from Drew University, and a B.A. in Political Science from Gettysburg College. 
Bahaudin G. Mujtaba is a Professor of Human Resources Management at the Huizenga College of Business and Entrepreneurship of Nova Southeastern University. For 16 years, Bahaudin worked in the supermarket industry and was a certified Professional Food Managers in the state of Florida. Bahaudin was also a ServSafe trainer for retail managers in Florida. Bahaudin is the author and coauthor of books dealing with diversity, ethics and business management. During the past thirty years, he has had the pleasure of working with managers and human resource professionals in the United States, Brazil, India, Afghanistan, Pakistan, St. Lucia, Grenada, Vietnam, Malaysia, Thailand, Bahamas, and Jamaica. This diverse exposure has provided him many great insights in management from the perspectives of different firms, people groups, and countries.

Stephen Muffler is a full-time attorney and member of the Florida Bar since 1993 and an adjunct professor of Business Law and Ethics at Nova Southeastern University in Ft. Lauderdale, Florida since 1999. He was awarded the Adjunct Professor of the Year at H. Wayne Huizenga School of Business and Entrepreneurship of Nova Southeastern University in 2007. Professor Muffler has taught graduate business law, international business law and business ethics classes in five countries and also currently teaches business law and criminal justice classes at Broward College in Broward County Florida. He was a former legal assistant to the Florida Bar's ethics enforcement branch in Miami Florida and former Special Public Defender for the $17^{\text {th }}$ Judicial Circuit, in and for Broward County Florida. He currently is an Assistant General Counsel to the Broward County Sheriff's Department, the largest fully accredited public safety agency in the State of Florida. Professor Muffler's civic service has included being the Chairman of the City of Fort Lauderdale's Citizen Police Review Board and the Executive Director of the City of Key West's Citizen Review Board, both of which investigate and/or review administrative complaints against municipal police officers. He has authored and co-authored various articles on legal \& ethical topics, and occasionally lectures by invitation to national and local organizations. He holds a LL.M in International Law from the University of Miami, School of Law and graduated with Honors with a J.D. from Nova Southeastern University and a B.S. in Criminal Justice from University of Missouri-St. Louis.

Marissa Samuel is an adjunct Professor of Business Law, Ethics and Management at the H. Wayne Huizenga College of Business and Entrepreneurship at Nova Southeastern University. Marissa also specializes in test preparation, focusing on the LSAT and GMAT exams. Outside of teaching, Marissa is a transactional attorney for small businesses. Prior to teaching for Nova, Marissa worked at the Miami office of McDermott, Will \& Emery, where she practiced corporate law, primarily in the area of mergers and acquisitions. Marissa holds a J.D. from Columbia Law School, an M.B.A from Columbia Business School, and a B.S. in Industrial \& Labor Relations from Cornell University.

Nicolas-Michel Polito is a graduate of Rutgers University, The Culinary Institute of America, and Nova Southeastern University. He has an MBA in Finance from Nova Southeastern. Currently, he is in the Master of Accounting program at Fairleigh Dickenson University. Previously Nick has worked for the 3 Michelin star restaurant, Per Se, in New York City. Nick currently is working as a chef developing recipes, frozen entrees, and read-to-eat foods notable for nutritional ingredients, cost-value, and strict compliance with government standards. Also, Nick works as a consulting chef for the following organizations: Wegmans, Kings, Shoprite, Fairway, Babeth's Feast, Amtrak, and Thumann's. 